\title{
GE冬ротато
}

\section{Baseline Study Rangpur GEOPOTATO}

Annette Pronk, Geert Kessel, Hasib Ashan, Md. Masudur Rahman, Shafi Abdulla Hil, Nazrul Islam, J ean-Marie Michielsen, Huib Henqsdijk

GEOPOTATO

External Report 4
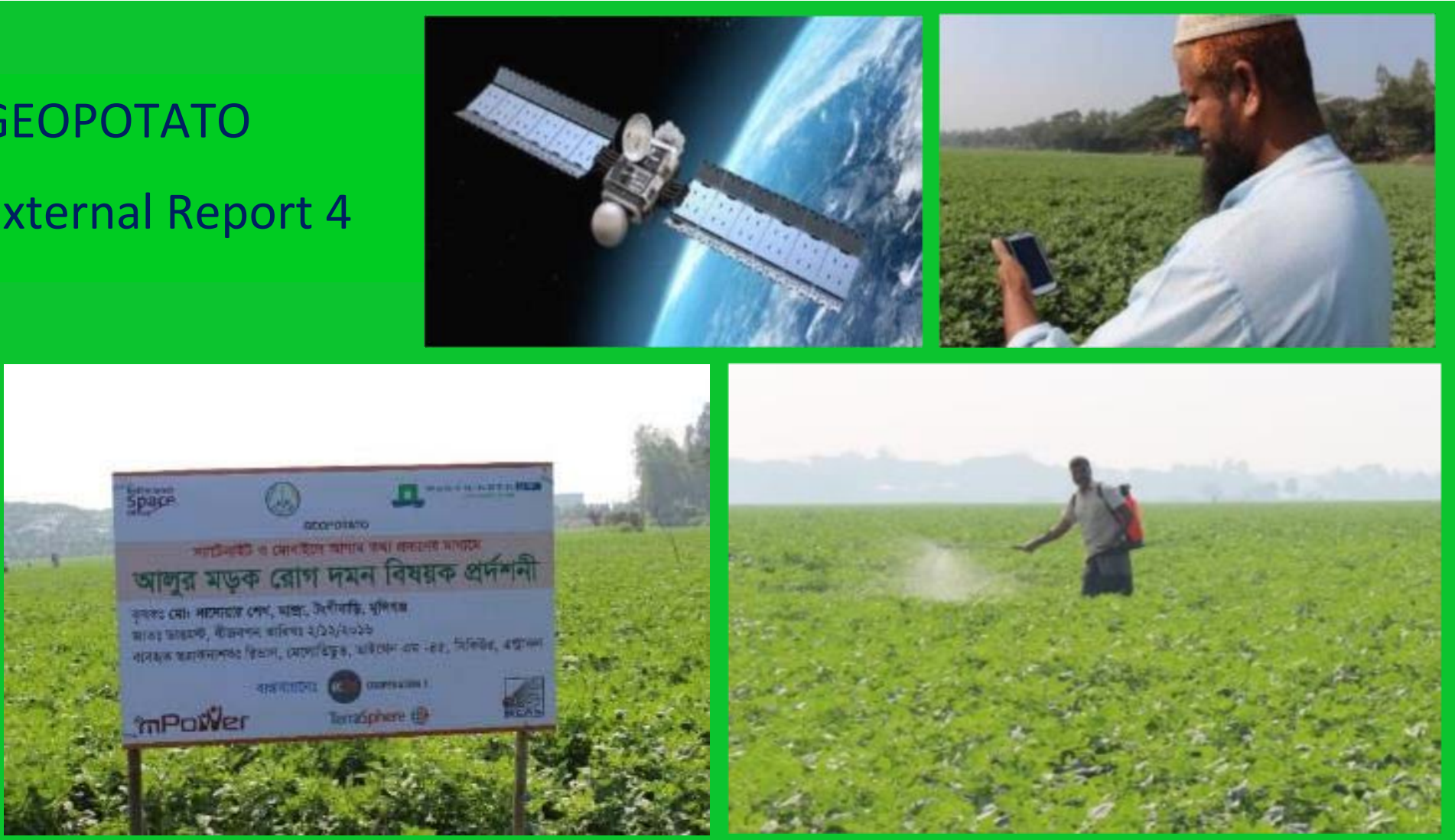


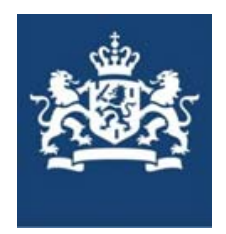

The GEOPOTATO project develops and implements a decision support service (DSS) in Bangladesh to control the late blight disease in potato. Satellite data and various models are important aspects of the DSS. GEOPOTATO aims at becoming the preferred agricultural advice service for potato farmers in Bangladesh. GEOPOTATO is financed by the G4AW program of the Dutch Ministry of Foreign Affairs, which is executed by the Netherlands Space Office (NSO).

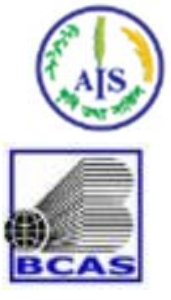

ICCO COOPERATION >

\section{"nPolver}

\section{TerraSphere 菬:}

Agricultural Information Services, Ministry of Agriculture, Bangladesh

Bangladesh Centre for Advanced Studies, Bangladesh

ICCO Cooperation, Bangladesh

mPower Social Enterprise Ltd., Bangladesh

TerraSphere, The Netherlands

Suggested citation for this report:

Pronk, A.A.,G. Kessel, Hasib Ashan, Md. Masudur Rahman, Shafi Abdulla Hil, Nazrul Islam, JM

Michielsen, H. Hengsdijk, 2017. Baseline Study Rangpur GEOPOTATO. GEOPOATO Report 4. Dhaka / Wageningen

The pdf file is free of charge and can be downloaded at https://doi.org/10.18174/448111.

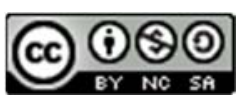

GEOPOTATO uses a Creative Commons Attribution-Non-Commercial-Share Alike 4.0 International License for its reports

The user may copy, distribute and transmit the work and create derivative works. Third-party material that has been used in the work and to which intellectual property rights apply may not be used without prior permission of the third party concerned. The user must specify the name as stated by the author or licence holder of the work, but not in such a way as to give the impression that the work of the user or the way in which the work has been used are being endorsed. The user may not use this work for commercial purposes. 


\section{Baseline Study Rangpur GEOPOTATO}

Annette Pronk, Geert Kessel, Hasib Ashan, Md. Masudur Rahman, Shafi Abdulla Hil, Nazrul Islam, J ean-Marie Michielsen, Huib Hengsdijk

GEOPOTATO External Report 4 


\section{Ge冈ه}




\section{Table of Contents}

\section{Summary 7}

1

General Introduction

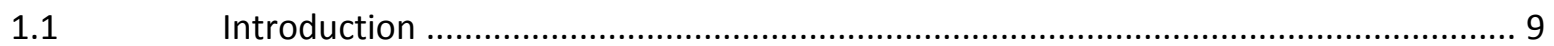

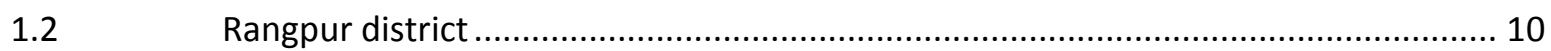

Potato production in Rangpur district........................................................... 11

$2 \quad$ Materials and Methods ...................................15

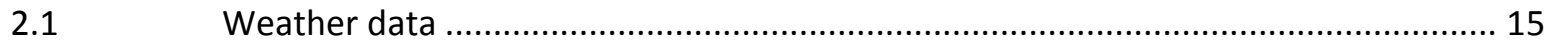

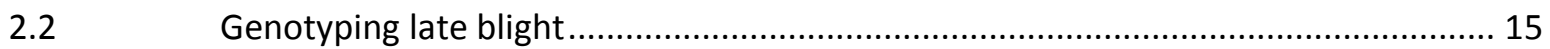

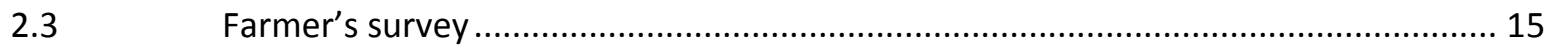

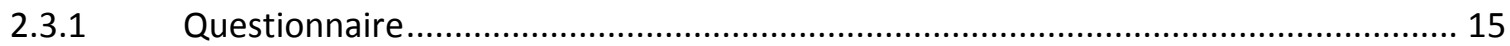

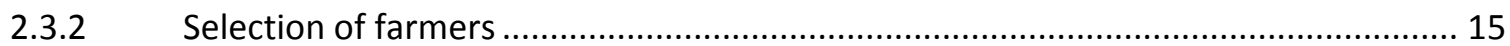

2.3.3 Enumerators and survey implementation ....................................................... 16

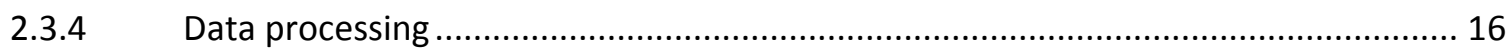

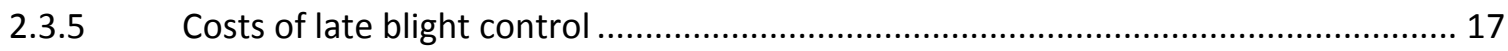

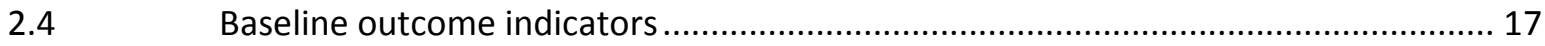

3

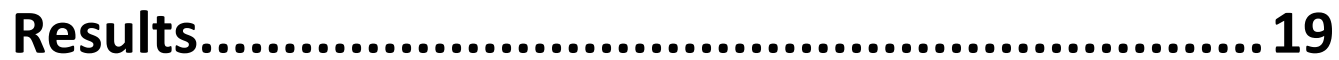

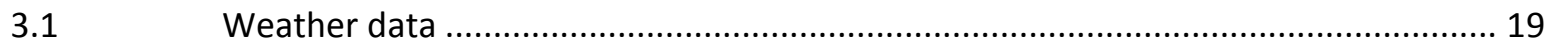

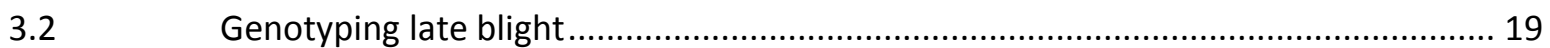

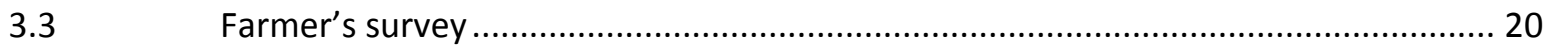

3.3.1 General information of interviewed farmers ................................................ 20

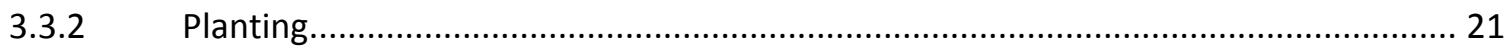

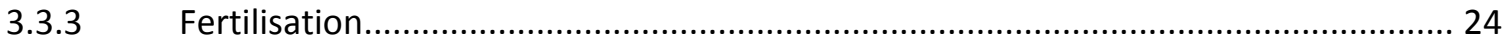

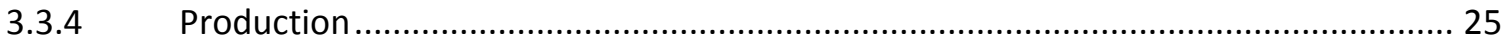

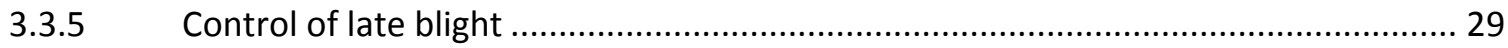

Baseline outcome indicators ...................................................................... 32

$4 \quad$ Discussion and conclusions ................................3 34

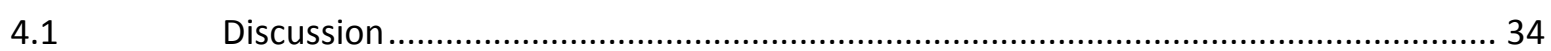

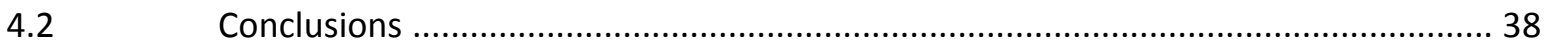

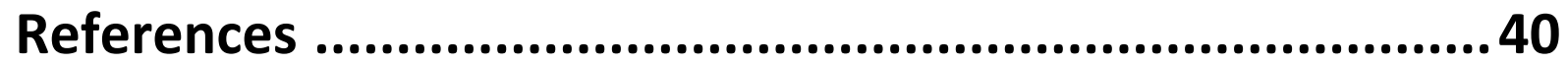


Annex I: Fertilizer Recommendation Guide: Root and Tuber Crops: Potato (Solanum tuberosum) (FRG 2012) . 41 Annex II: GEOPOTATO Baseline questionnaire Rangpur (2016-17) 


\section{Summary}

GEOPOTATO is one of the projects funded within the Geodata for Agriculture and Water (G4AW) facility, which improves food security in developing countries by using satellite data. The GEOPOTATO project develops a decision-support service (DSS) for farmers in Bangladesh for an optimal control strategy of the late blight disease in potato. Late blight (Phytophthora infestans) is a highly infectious and destructive fungal disease in Solanaceae crops, i.e. among others potatoes and tomatoes. The Netherlands Space Office (NSO) is executing this programme, commissioned by the Dutch Ministry of Foreign Affairs.

The objective of the GEOPOTATO project is to reach 100,000 potato farmers with such the DSS after three years. The GEOPOTATO project selected two major potato-producing regions in Bangladesh (Munshiganj and Rangpur) to introduce the service. This report describes the results of a baseline study with the state-of-the-art of potato production using data of the 2016/2017 potato season in Rangpur.

The objective of this baseline study is:

- To better understand the behaviour of farmers, their needs, bottlenecks and barriers of late blight control,

- To collect information on the fungicides (pesticides) used and,

- To quantify indicators which are used to assess the performance of the GEOPOTATO service, i.e. (baseline values for outcome indicators).

The baseline study comprises information from different project activities in 2017 ranging from field trips, characterisation of the late blight genotypes prevailing in Rangpur, a dedicated baseline survey carried out under potato farmers in Rangpur, information from literature and from stakeholders in the potato value chain.

The conclusions of the baseline study with respect to the methodology used are:

- The baseline survey was performed in between potato growing seasons and used the farmers' memory to answer the questions, which may therefore be considered to have a more general character than answers for a specific growing season. This should be kept in mind when reading the results and conclusions.

- The local extension agents, who selected the farmers for the survey, selected larger farmers. Therefore, the results may be not completely representative for potato farmers in Rangpur.

- The questionnaire included the entire list of allowed fungicides for late blight control in Bangladesh, which was a major improvement compared to the approach used in Munshiganj.

- The chosen methodology of interviewing farmers on their behaviour, needs, bottlenecks and barriers with respect to late blight control yielded very useful information, which is a solid starting point to introduce the late blight alert service. 
The conclusions of the baseline study with respect to the survey are that:

- Farmers have a great need to improved control of late blight.

- Farmers are eager to learn about improved strategies to control late blight.

- Late blight pressure is severe due to climatological conditions.

- Farmers' awareness of late blight is high.

- In general, farmers timely spray preventive fungicides but effectiveness of sprays is unclear as farmers observe late blight.

- Farmers apply mainly curative Metalaxyl containing fungicides, which have little/no effect on the control of the found Metalaxyl resistant strain of late, blight in Rangpur.

- Other options to reduce late blight related yield losses might be included as a package to reduce losses.

The conclusion of the baseline study with respect to the outcome indicators are that:

- The starting point for the different indicators shows high potential to be improved as the late blight alert service is introduced.

The need for the late blight alert service was clearly identified in this study. However, some potential bottlenecks have also been identified and which may be difficult to change or improve during the project period. The two most important pitfalls are:

- The availability and use of counterfeit fungicides may lead to disappointing control of late blight, even if farmers use the alert service. Due to counterfeit fungicides trust in the service may be lost and hampering adoption.

- The unavailability of adequate fungicides to control preventively and curatively late blight including the Metalaxyl resistant strain Blue13, might compromise an effective introduction and effective use of the alert service. This conclusion holds for Rangpur as it did for Munshiganj and may well be for all potato producing regions in Bangladesh. 


\section{General Introduction}

\subsection{Introduction}

GEOPOTATO is one of the projects funded within the Geodata for Agriculture and Water (G4AW) facility, which improves food security in developing countries by using satellite data. The Netherlands Space Office (NSO) is executing this programme, commissioned by the Dutch Ministry of Foreign Affairs.

The GEOPOTATO project develops a decision-support service for farmers in Bangladesh for an optimal control strategy of the late blight disease in potato. Late blight (Phytophthora infestans) is a highly infectious and destructive fungal disease in Solanaceae crops, i.e. among others potatoes and tomatoes. Especially under favourable weather conditions, i.e. temperatures between 12 and $25^{\circ} \mathrm{C}$ and a relative atmospheric humidity $>85 \%$, the disease spreads very quickly through wind and water and can have devastating effects on the potato crop and production. Through development of a decision-support service (DSS) based on a combination of satellite information and models infection periods of late blight can be forecasted. A timely advice through mobile phone for the application of an appropriate fungicide help farmers to prevent the infection of the potato crop with late blight.

Bangladesh is area-wise the third largest potato producer in Asia after China and India and among the top 10 of the potato producing countries in the world. The harvested potato area in Bangladesh is 469,474 ha (average 2014-2016; FAOSTAT) making it the second major food crop in Bangladesh after rice, which is mainly grown for subsistence. In contrast, potato is grown as the major cash crop during the dry winter season of Bangladesh (December - March). It is estimated that over 750,000 small farmers in Bangladesh produce a potato crop (Egger 2012). Because of the short growing cycle (approximately 90 days), the returns on investment for farmers are quick and also potentially high compared to other crops that can be grown in the winter season.

The objective of the GEOPOTATO project is to reach 100,000 potato farmers with the DSS after three years. Major potato production areas are in the district Munshiganj and the area surrounding Rangpur. The GEOPOTATO project has selected Munshiganj as region to develop and introduce the service in the season 2016/2017. Upscaling of the service to Rangpur is foreseen in the season 2017/2018. Baseline studies are carried out in both Munshiganj and Rangpur to better understand the needs, practices and performance of farmers, and the context of potato farming in these regions. Results of the baseline studies will also be used as benchmark to assess the change in management and performance of farmers after the introduction of the DSS.

The objective of this baseline study is:

- To better understand the behaviour of farmers, their needs, bottlenecks and barriers of late blight control,

- To collect information on the fungicides used and

- To quantify the baseline values for the outcome indicators of the GEOPOTATO DSS.

The report comprises information from different project activities in 2017 ranging from field trips, characterisation of the late blight genotypes prevailing in Rangpur, a dedicated baseline survey carried out under potato farmers in Rangpur, information from literature and from stakeholders in the potato value chain. The bulk of this report describes the results of the baseline survey in Rangpur carried out in the fall of 2017 and of which most of the information refers to the potato season 2016/2017. During 2017, local and international partners of GEOPOTATO visited the Rangpur district 
frequently. These field visits provided considerable information about the (context of) potato production in Rangpur. The information was obtained from the local agents of the Department of Agricultural Extension (DAE) as well as potato farmers in Rangpur. Although much of this information was qualitative and sometimes anecdotic, throughout this report information of the field visits is used to deepen understanding of more quantitative data and information.

In the rest of this Chapter, first general information on Rangpur is given and second, a general overview of potato production in Rangpur based on field visits and discussions with local potato specialists, extension agents and farmers. In Chapter 2, the various data and information sources are described. Chapter 3 gives a compilation of the major findings and characteristics of potato production in Rangpur. The majority of the information provided in Chapter 3 is based on the dedicated survey carried out under 455 potato farmers in Rangpur. Finally, in Chapter 0 major conclusions of this study are summarized and the main outcome indicators are discussed that will be used to assess the effects of the GEOPOTATO DSS in the future.

\subsection{Rangpur district}

Bangladesh has eight administrative divisions named Barisal, Chittagong, Dhaka, Khulna, Mymensingh, Rajshahi, Rangpur and Sylhet. The divisions are subdivided into in total 64 districts of which Rangpur district is within the Rangpur division (Figure 1.1). Rangpur district measures about $23,000,000 \mathrm{ha}^{1}$ and is located northwest of the Capital Dhaka. The district is surrounded by other districts of Bangladesh. The district is relatively high above sea level, about $50 \mathrm{~m}$, and flat. Rice is the major crop especially in summer when rivers increase and support flooding of fields. In winter, paddy rice as well as potatoes, maize and leafy vegetables are produced. Fields are furrow irrigated.
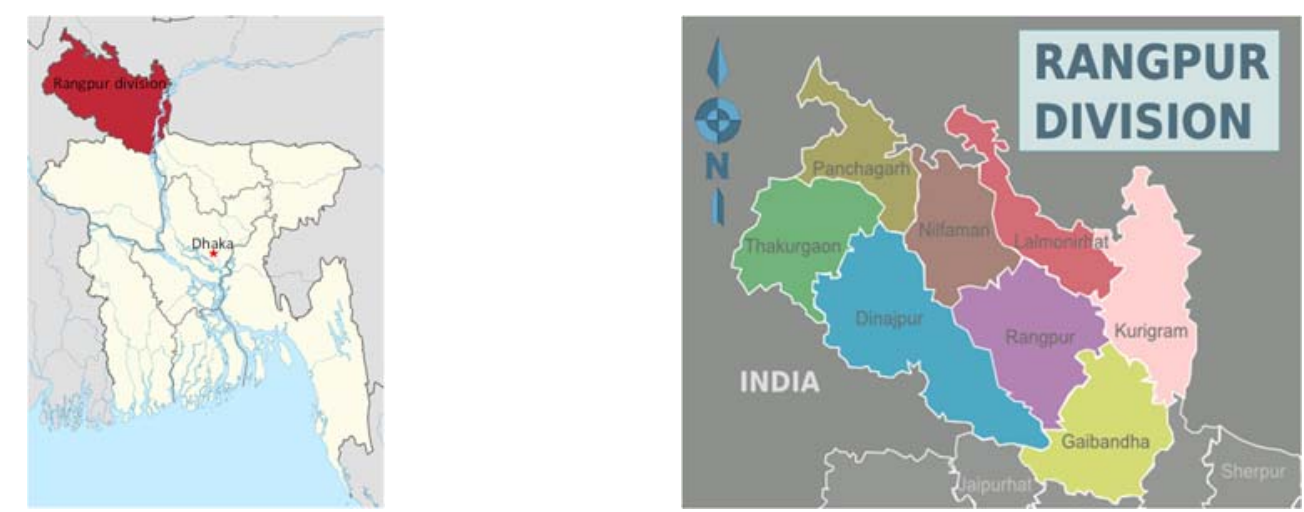

Figure 1.1 The location of the Rangpur division (Bordeaux red) and the Capital Dhaka (red dot, left) and the districts in Rangpur division (right). Source: Wikipedia

The Rangpur district is divided into 8 sub-districts (upazila's), named Badarganj, Gangachara, Kaunia, Mithapukur, Pirgachha, Pirganj, Rangpur Metro \& Rangpur Sadar and Taraganj, Figure 1.2). Rangpur division has 65 agricultural information community centres (AICC) with 25 to 50 members each. These centres provide community based trainings on agricultural practices on a monthly basis. Rangpur district has nine AICC's, one in each sub-district and two in Rangpur Sadar \& Metro. The

${ }^{1}$ https://en.wikipedia.org/wiki/Bangladesh\#Administrative_geography, 10 J anuary 2018 
centres are equipped with laptops, beamers, and other communication means, machinery and small means to support market access such as scales, bags etc.

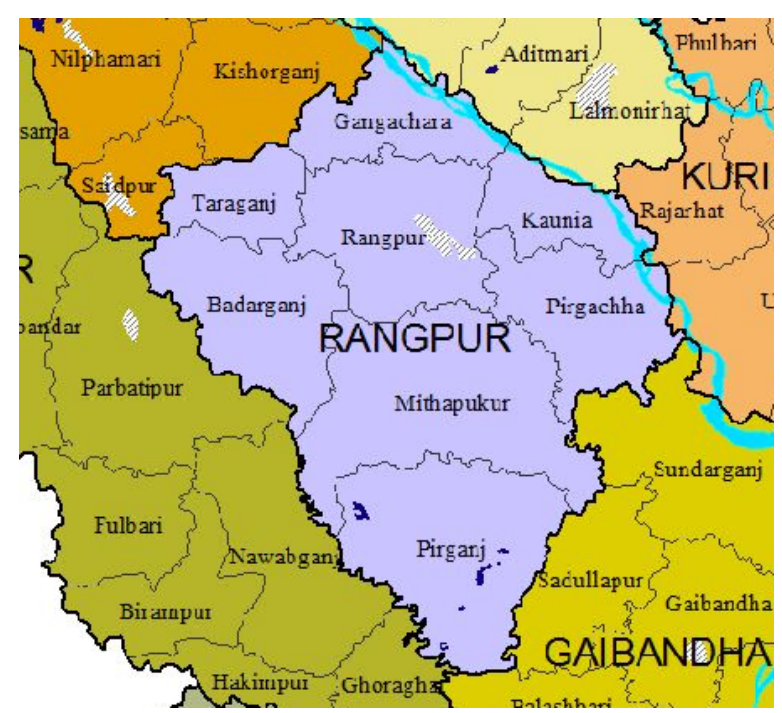

Figure 1.2 Rangpur district with its eight sub-districts (upazila's). Source: Bangladesh Agricultural Research Council

\subsection{Potato production in Rangpur district}

The total potato production in Rangpur district is estimated at 1.04 million tonnes, with an average yield of \pm 20 tonnes/ha in the season 2015-16 (Figure 1.3, left). This is in line with the average potato yield in Bangladesh which was approximately 20 tonnes/ha in 2016 (FAOSTAT).
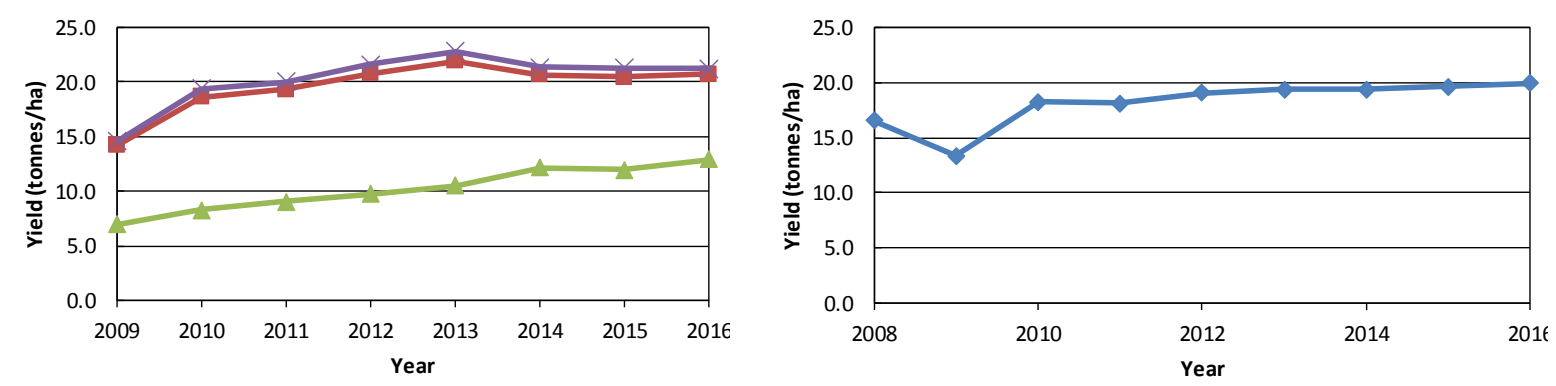

$=$ Local \& High Yielding Varieties $\longrightarrow$ Local varieties - High Yielding Varietis

Figure $1.3 \quad$ Average yield over the past years in Rangpur district (left) and Bangladesh (right). Sources: FAO and Government of Bangladesh 
Farmers produce potatoes on small plots of 0.25 to 0.5 ha. Farmers own the land but also rent land with lease prices of about $550 \mathrm{BDT}^{2}$ per decimal ${ }^{3}$ per season. Potato is an important cash crop for Rangpur farmers in the dry winter season from November to March. Potato is in general alternated with paddy rice in the wet season.

Mechanised ploughing / power tiller (Figure 1.4) up to $10-15 \mathrm{~cm}$ (4-6 inches) deep is common before planting. The predominant potato variety used by farmers is Cardinal from Agrico. Other popular varieties are Diamant and Asterix. About $5-10 \%$ of the potato seed is new to the farmer, i.e. bought from outside his farm each year. The remainder is graded from last year's harvest and cold stored until the next potato season starts in November. Commonly, potato seeds are cut in pieces to reduce seed costs. Seeds of $60-70$ grams are cut in two, smaller seeds are sometimes planted whole and larger seeds are cut into 4 pieces. The cut seed pieces are not treated with a pesticide before planting. Planting is done manually with a row distance of approximately $50-70 \mathrm{~cm}$ and plant distances of $10 \mathrm{~cm}$ in the row are common, totalling over 250,000 plants per ha. Ridges are made to facilitate furrow irrigation. The number of plants is extremely high compared to planting densities of potatoes in the Netherlands, which typically range between 30,000 and 50,000 plants/ha. However, where the cut seed potato pieces in Bangladesh usually produce one healthy potato main stem per planted cutting, a non-cut but well sprouted potato can have up to six potato main stems depending on the size of the planted seed potato. Stems originating from the potato are the so-called main stems and they are tuber-bearing stems. As the number of main stems is best related to yield, the Dutch target value varies between 15 and 22 main stems for ware potatoes in the Netherlands. Plant densities of 50,000 plants per ha with 5 or 6 main stems per potato are therefore comparable to densities in Bangladesh but differently obtained.
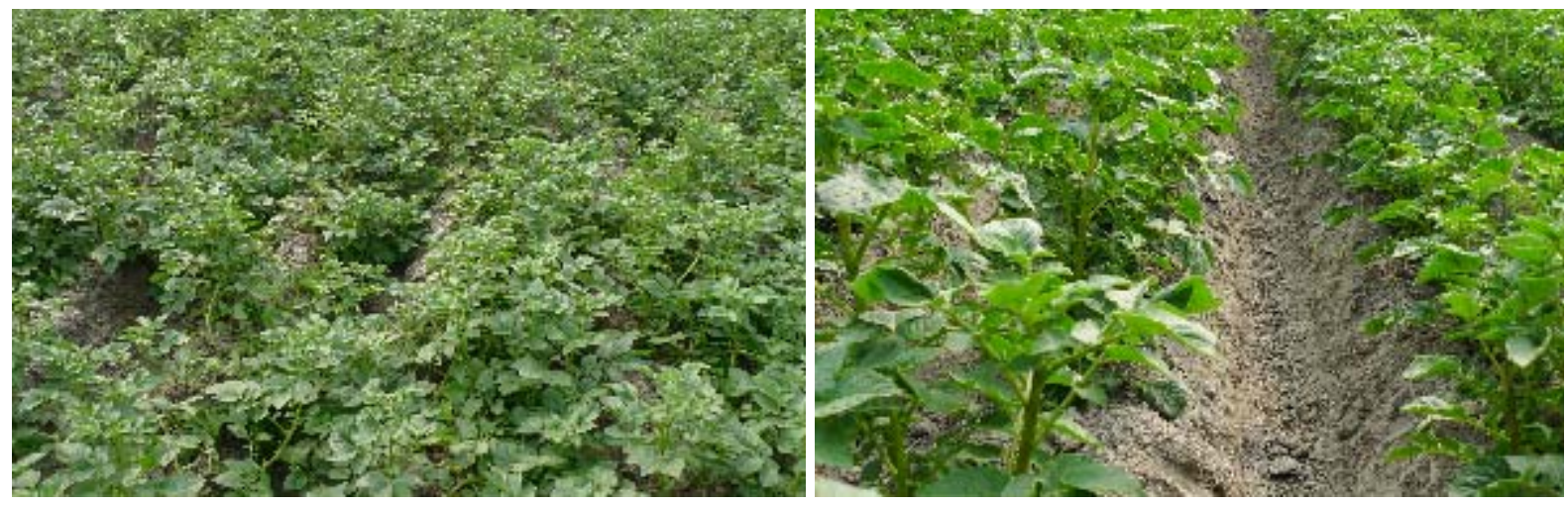

Figure 1.4 Landscape in Rangpur with extensive potato fields showing the ridges.

Common fertilizer practices are 350 - $600 \mathrm{~kg}$ Urea/ha, while the recommendation is $400 \mathrm{~kg}$ Urea/ha depending on soil fertility (Annex I). Phosphate is applied as Triple Super Phosphate (TSP) at a rate of $700 \mathrm{~kg} / \mathrm{ha}$, while the recommend rate is $500 \mathrm{~kg} / \mathrm{ha}$. Potassium is applied as Potash at a rate of 600 $\mathrm{kg} / \mathrm{ha}$, while the recommendation is $400 \mathrm{~kg} / \mathrm{ha}$. Fertilizers are subsidized and average costs in 2016 were 16 BDT per kg Urea, 22 BDT per kg TSP and 15 BDT per kg of Potash. Fertilizers are in general

\footnotetext{
2 One Bangladesh Taka (BDT) equals 0.0119 Euro; 1 Euro = 84 BDT (November 22, 2016)

3 One decimal is a unit of area used in Bangladesh and equals approximately $1 / 100$ acre $\left(=40.46 \mathrm{~m}^{2}\right) .100 \mathrm{decimal}^{3} 4046 \mathrm{~m}^{2}$ and 250 decimal is about one ha which unit will be used throughout the report.
} 
subsidised by the Government, TSP by $35 \%$, and Urea by $10 \%$. In addition, the electricity for pumping irrigation water is subsidised.

Major crop protection problems are late blight, scab and viruses. Late blight periodically destroys the potato crop with the last major incident reported in the potato growing season of 2006-2007 when between $50 \%$ to almost $80 \%$ of the yield was destroyed nationwide (Dey et al. 2010). According to farmers, not all crop protection agents are working properly. Some 40 days after planting farmers start to spray against late blight. The spray strategy starts with Mancozeb, $3-5 \mathrm{~kg} / \mathrm{ha}$ at an interval of 10 days. Later in the season also Ridomil Gold MZ 68 WG (Mancozeb (64\%) + Metalaxyl (4\%), Annex I), $2 \mathrm{~kg} / \mathrm{ha}$ is used. Other available fungicides are Acrobat MZ (500 g/l Mancozeb (60\%) + Dimethomorph (9\%)) and Melody duo 66.8 WP (Iprovalicarb + Propineb 6675 WP (5.5\% + 61.25\% $\mathrm{w} / \mathrm{w})$.

The potato crop is commonly irrigated 2 to 3 times per growing season using furrow irrigation. Commonly, the harvest starts in the last week of February or early March. By that time potato haulms have died because of the rapidly increasing daily temperature, although some farmers indicate to remove actively the foliage from the stems when still green. Around harvesting average daily temperatures range from 27 to $30^{\circ} \mathrm{C}$. Potatoes are manually harvested and, after 2 to 3 days field drying, temporarily stored at the field in piles covered with dead potato haulms (Figure 1.5).
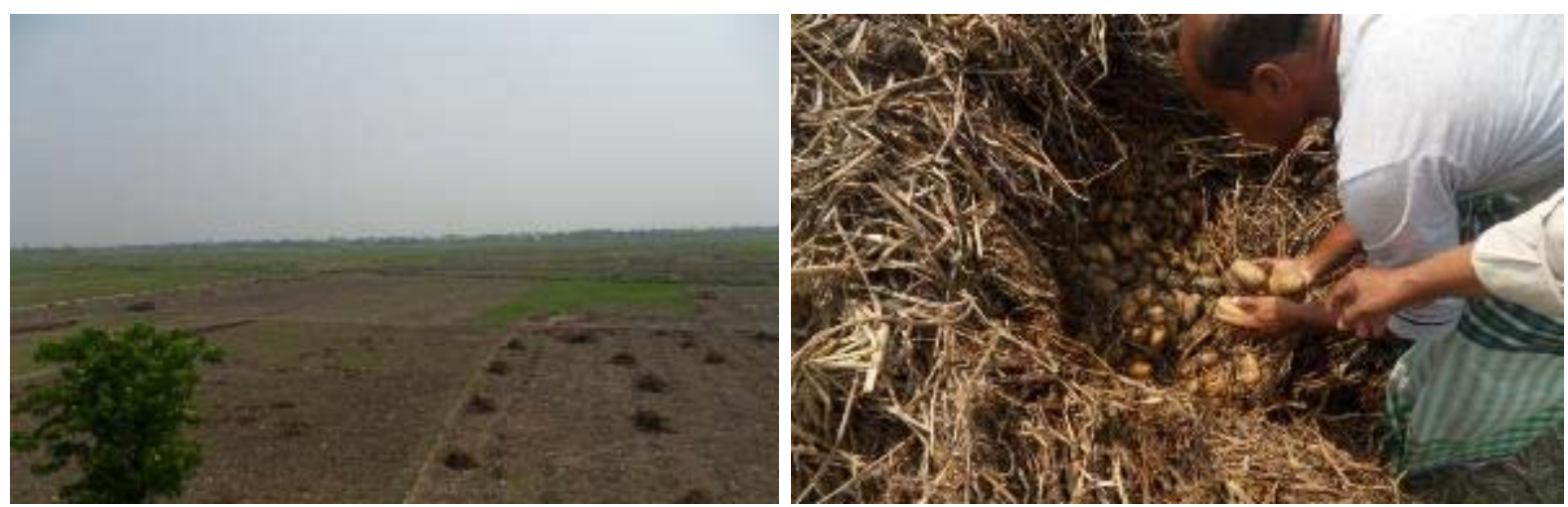

Figure $1.5 \quad$ Piles with potatoes after the harvest covered with potato haulms (March 2016).

After some time being stored in the field the potatoes are sold or brought to one of the 98 cold stores in Rangpur (Haque et al. 2018). Bags of $80 \mathrm{~kg}$ are stored for 7 to 8 months at approximately $10^{\circ} \mathrm{C}$ for 250 to $300 \mathrm{BDT} / \mathrm{bag}$. Farmers prefer to store potatoes and benefit from higher prices later in the year: at harvest, prices for potatoes are around $10 \mathrm{BDT} / \mathrm{kg}$ while prices increase to $20 \mathrm{BDT} / \mathrm{kg}$ later in the season (Figure 1.6). In Bangladesh, 20 to 25\% is stored in cold storages (Haque et al. 2018). 

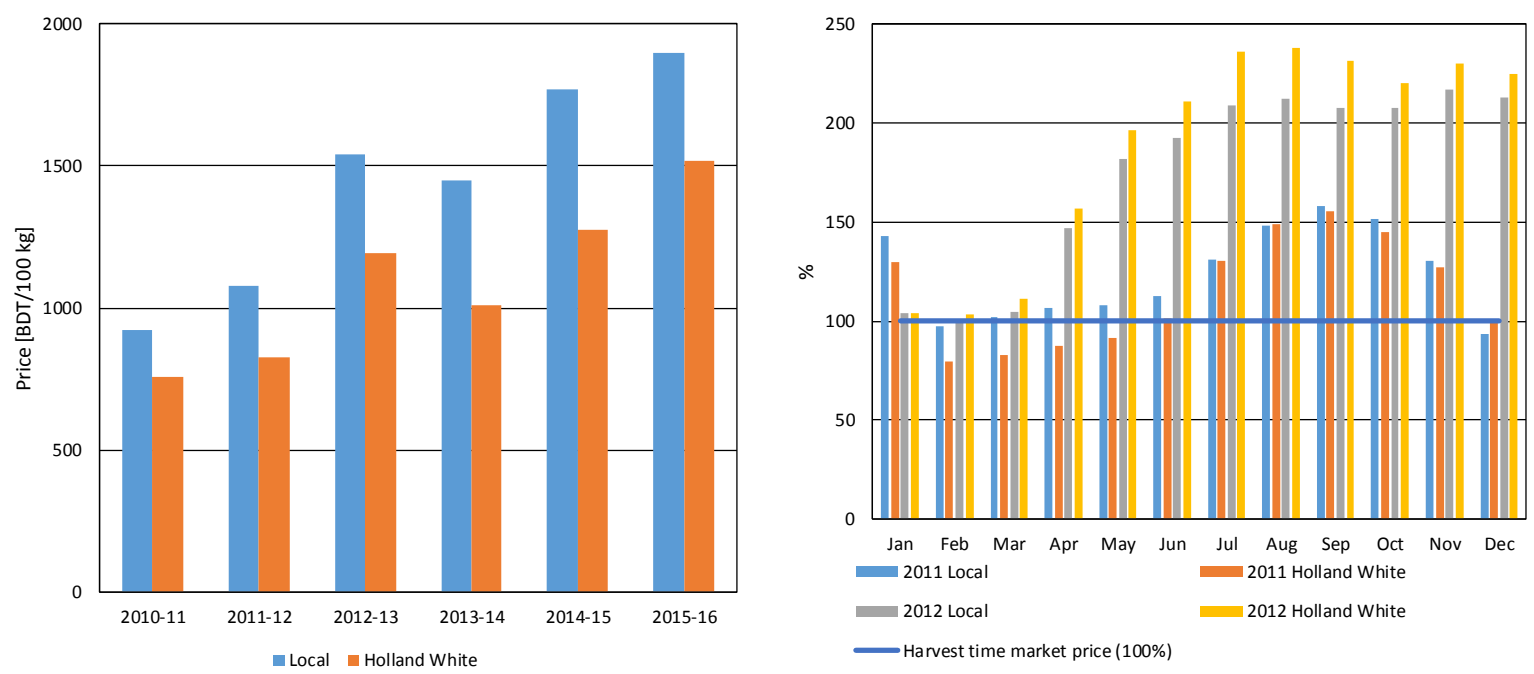

Figure 1.6 Harvest market price of local varieties and Holland White (high yielding varieties, left) and price variations within the year expressed as percentage of the harvest market price for both varieties in 2011 and 2012 (right, (Bangladesh Bureau of Statistics (BBS) 2016)). 


\section{Materials and Methods}

\subsection{Weather data}

The Bangladesh Meteorological Department (BMD) for the Rangpur district made weather data available. Three hourly recordings were used to derive the maximum and minimum daily temperatures and maximum and minimum daily humidity.

\subsection{Genotyping late blight}

During a visit in January 2017, potato late blight was sampled using FTA card to identify the Phytophthora infestans genotypes present in Rangpur. Different $P$. infestans may differ in fungicide resistance and virulence to the potato varieties grown. Blue13 (EU13_A2), currently is the most widespread $P$. infestans genotype/clonal lineage and is known to be fully resistant to Metalaxyl/Mefenoxam and similar active ingredients such as Benalaxyl.

Eight $P$. infestans samples were collected 31 January and 1 February 2017. SSR genetic fingerprints were produced using the EuroBlight 12-plex SSR set (Li et al. 2010). The SSR results were analysed using genemapper software and known genotypes/clonal lines were identified.

\subsection{Farmer's survey}

\subsubsection{Questionnaire}

The questionnaire of the baseline survey was improved according to the findings of the baseline survey in Munshiganj (Annex II). The most important improvement was the use of a predefined list of 218 fungicides that are formally approved in Bangladesh based on the list of Registered Agricultural Pesticides, bio pesticides \& Public Health Pesticides in Bangladesh Approved for late blight control of potatoes (www.bcpabd.com/pdf/RegisteredPesticidesList.pdf). The focus on the major characteristics of potato production and specifically of current late blight control practices by farmers was supplemented with questions on which fungicides were used and how many fungicide sprays were applied. The questionnaire required relatively little time and effort from the farmers to answer.

All questions refer to the potato season 2016-2017 and refer to one potato plot (largest or best performing) of the interviewed farmer.

\subsubsection{Selection of farmers}

The local Department of Agricultural Extension (DAE) in Rangpur selected 455 potato farmers. The intension was to select a representative sample of farmers from eight sub-district in Rangpur of farmers who have a mobile telephone and phone number. The sub-districts were Badarganj (50), Gangachara (55), Kaunia (50), Mithapukur (50), Pirgachha (52), Pirganj (50), Rangpur Metro \& Rangpur Sadar (98), Taraganj (50)(Table 3.2). 


\subsubsection{Enumerators and survey implementation}

The survey was carried out in the same way as the survey of the baseline study of Munshiganj (Pronk et al. 2017). In short, enumerators, quality control staff and a team leader of the Development Research Institute in Dhaka performed the survey after a training in the field. Programming for a mobile application and translation into English of the survey results were done by mPower. The survey was carried out between 8 and 11 September 2017.

\subsubsection{Data processing}

Data were cleaned from missing values and some unreliable recordings. In some cases, the total entry of a farmer was dismissed and sometimes records were improved so they could be included in the results. The questionnaire included the entire list of allowed fungicides for late blight control (217 products in total), which was a major improvement compared to the questionnaire of the baseline survey used in Munshiganj (Pronk et al. 2017). All mentioned products were included in the results and typing errors in the fungicide names were avoided in this way.

The used fungicide products were qualified according to the type(s) of active ingredient(s): preventive, preventive and slightly curative, preventive and curative, preventive and curative resistance or curative resistance. Fungicide products can contain different active ingredients with specific biological efficacies (Figure 2.1). Preventive fungicide products, also called protectants, contain active ingredients that control late blight through a protective cover on the potato leaves which prevents spores to germinate. Curative fungicide products contain active ingredients that penetrate into the leaves where they prevent growth of late blight. Some curative fungicide products have active ingredients that prevent late blight to develop spores, the so called anti sporulants. Some preventive fungicide products contain active ingredients that control late blight mainly through a protective cover but a small quantity of active ingredient penetrates into the leaves to prevent growth of late blight. These products have preventive and slightly curative active ingredients. Some curative fungicide products contain active ingredients of which no effect is to be expected on late blight control, as late blight is resistant to the active ingredient.

The overall use of fungicides of one farmer is subsequently grouped into one of the following five categories:

1. Use of preventive fungicide products only,

2. Use of preventive and slightly curative fungicide products,

3. Use of preventive and curative fungicide products,

4. Use of preventive and curative resistance fungicide products,

5. Use of curative resistance fungicide products only.

This grouping is used as a factor in the unbalanced analysis of variance to explore effects of the use of type of active ingredients on yield. 


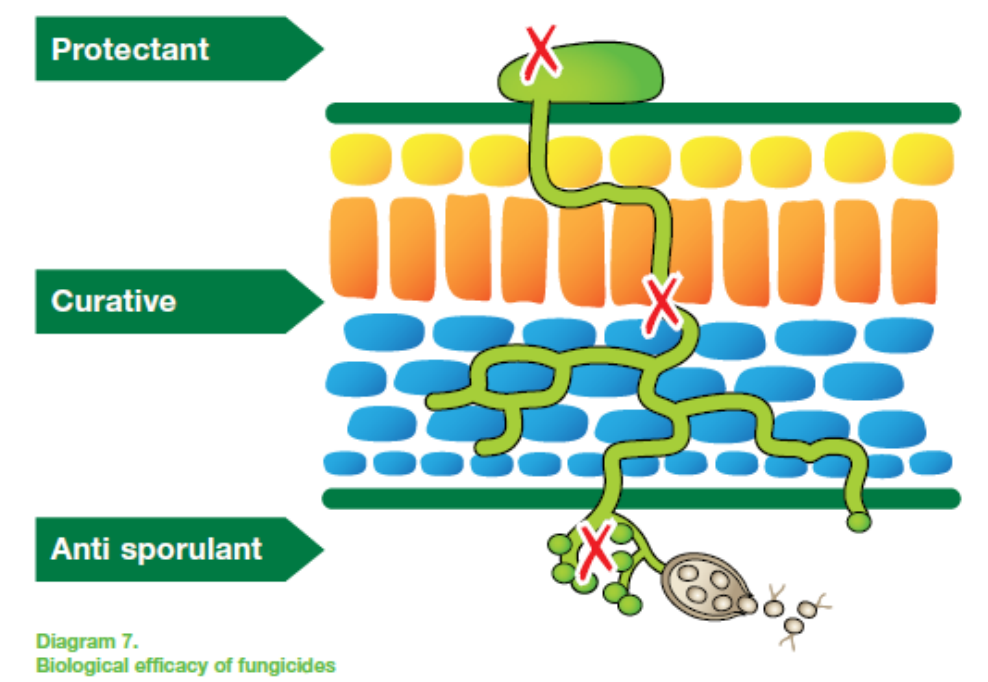

Figure 2.1 Pathways of biological efficacy of fungicide products.

\subsubsection{Costs of late blight control}

The costs of late blight control were calculated based on market prices for used fungicides in Rangpur, the advised spraying volume of $500 \mathrm{~L} / \mathrm{ha}$ (pers. comm. AIS and DAE.) and the recommended dosage for the fungicide used according to the Registered Pesticide List (www.bcpabd.com/pdf/RegisteredPesticidesList.pdf). Prices of fungicides were not yet available and costs are thus not calculated. This will be done at a later stage of the project.

\subsection{Baseline outcome indicators}

The late blight alert service of GEOPOTATO is evaluated based on different indicators. Following the annual progress report, the baseline study is used to calculate outcome indicators on different aspects of the project results. The outcome indicators are on sustainable food production, input use efficiencies, income and other outcomes.

The outcome indicator on sustainable food production is:

- Crop yield, ton/ha

The baseline survey yield is the basis for this indicator. In subsequent years, yield increase because of the service use is calculated.

The indicators on efficiencies are:

- Use of $\mathrm{N}$-fertiliser, and

- Use of fungicides.

The use of $\mathrm{N}$-fertiliser is expressed as $\mathrm{N}$-applied ( $\mathrm{kg} \mathrm{N} /$ ton product). The use of fungicides is expressed as fungicides applied as $\mathrm{kg}$ or $\mathrm{L}$ product/ha and as active ingredient as $\mathrm{kg}$ or $\mathrm{L} / \mathrm{ha}$. This is 
done as the expected changes may be in the amount of current products used and/or in the type of products used. Changes in the type of product used may result in lower levels of applied active ingredients while the amount of product is not changing and vice versa. The improved efficiencies will be later in the project expressed as a percentage improvement.

The indicator for income is:

- Costs of fungicides used in the standard scenario

The costs are not yet calculated as the prices of the fungicides used are not know (section 2.3.5) and will be done at a later stage of the project.

The indicator on other outcome is:

- The reduction in the use of curative fungicides containing Metalaxyl.

This is evaluated through two indicators. First, the percentage of products mentioned to be used by farmers with curative active ingredients containing Metalaxyl compared to all curative products is identified. This is done as the DSS supports the use of preventive fungicides and reduce the use of curative fungicides and dismisses the use of Metalaxyl containing fungicides (Pronk et al. 2017). Second, the percentage of fungicide applications with products containing Metalaxyl compared to all curative applications is calculated. This calculation is done as farmers may use less products but apply one product more often. With these two outcome indicators we can support changes in type of curative product used as well as the number of applications curative products are used. It is expected that the DSS will reduce the use of curative products in general and totally when containing Metalaxyl. As this is not expected to happen immediately, the reduction in Metalaxyl applications is also monitored. 


\section{Results}

\subsection{Weather data}

Figure 3.1 (left) shows the average monthly rainfall and average monthly minimum and maximum temperatures in Rangpur district. Total average annual rainfall is about $2150 \mathrm{~mm}$ per year. The most precipitation is between April and October, $2070 \mathrm{~mm}$ while hardly any precipitation is in the potatogrowing season, November until March.

The pattern in minimum and maximum temperature throughout the year shows lowest temperatures mid of January after which the temperature increases to average daily temperatures of slightly over $30^{\circ} \mathrm{C}$ and average daily minimum temperatures above $25^{\circ} \mathrm{C}$ in June, July, August and September. These high temperatures last until October when temperature minima and maxima gradually decrease until the end of the year.
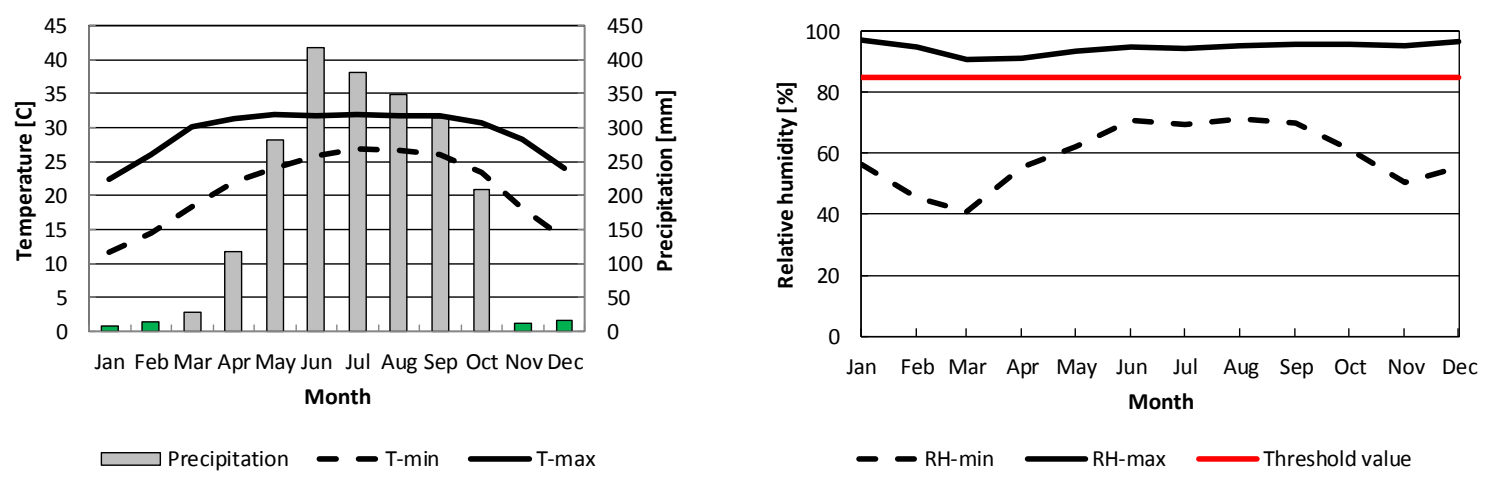

Figure 3.1 The average minimum $\left(T-\min ;{ }^{\circ} \mathrm{C}\right)$ and average maximum $\left(T-\max ;{ }^{\circ} \mathrm{C}\right)$ temperature and average total precipitation per month (Precipitation; $\mathrm{mm}$ ) (left) and the average minimum (RH-min; \%) and maximum (RH-max; \%) relative humidity for Rangpur (right) for the period 2006-2015. Green bars indicate the potato-growing season. Source: BMD.

Figure 3.1 (right) shows the average daily minimum and maximum relative humidity ( $\mathrm{RH}$ ) in Rangpur. The average daily maximum $\mathrm{RH}$ is above $85 \%$ year round indicating that conditions are favourable for late blight development as it is higher than the threshold level (red line). The average daily minimum $\mathrm{RH}$ is above $60 \%$ from May to October after which it slowly decreases and stays between 40 and $60 \%$.

\subsection{Genotyping late blight}

Similar to the situation in Munshiganj during the 2016 and 2017 potato growing seasons, the $P$. infestans samples taken early 2017 in Rangpur were all identified as Blue13 / EU13_A2 clonal lineage (Figure 3.2) (Pronk et al. 2017). This clonal lineage of European origin is fully resistant to Metalaxyl/Mefenoxam. The widespread use of Metalaxyl in Bangladesh very likely stimulated the complete displacement of earlier $P$. infestans genotypes by Blue13. Similar to the advice given earlier in Munshiganj, also in Rangpur it is important to avoid the use of Metalaxyl to control potato late blight efficiently. 


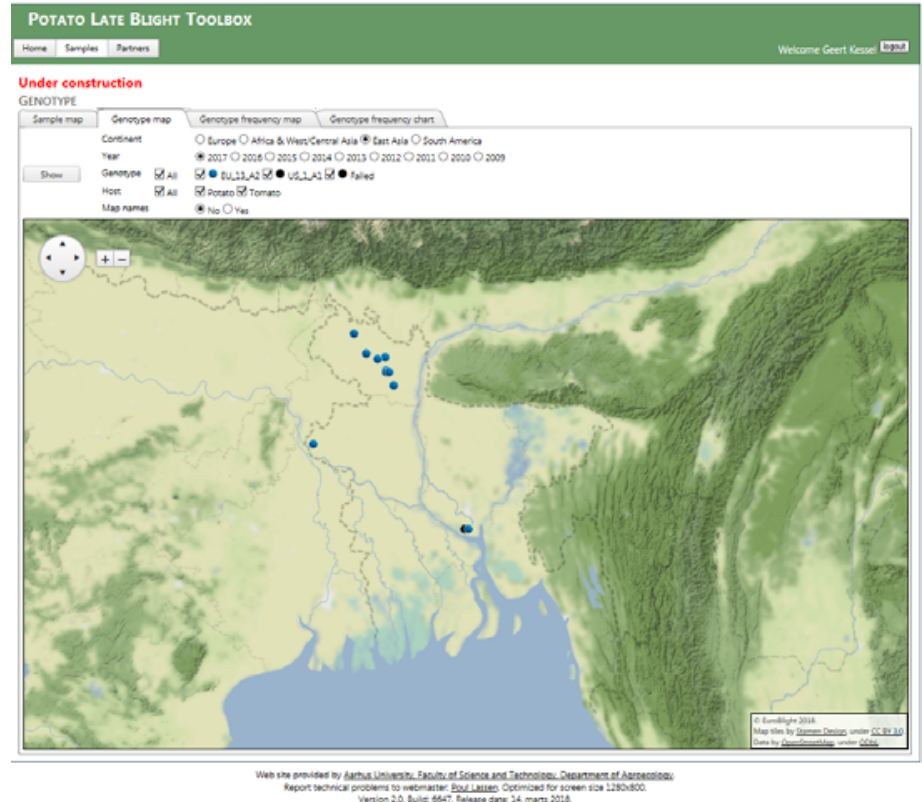

Figure 3.2 Locations (bleu dots) where Blue13 was identified early 2017

\subsection{Farmer's survey}

\subsubsection{General information of interviewed farmers}

Most farmers in the survey finished primary school (Table 3.1). Only seven farmers, which is $1.5 \%$ of the interviewed farmers had no education and are considered illiterate.

Table 3.1 Education level of farmers in Rangpur and its sub-district.

\begin{tabular}{lllll}
\hline sub-district & No education & Primary school & Secondary school & Higher secondary school \\
\hline Badarganj & 0 & 12 & 20 & 18 \\
Gangachara & 2 & 5 & 28 & 20 \\
Kaunia & 0 & 21 & 16 & 13 \\
Mithapukur & 0 & 16 & 22 & 12 \\
Pirgachha & 0 & 15 & 21 & 16 \\
Pirganj & 5 & 10 & 17 & 18 \\
Rangpur Metro \& Sadar & 0 & 21 & 36 & 41 \\
Taraganj & 0 & 13 & 33 & 4 \\
\hline Rangpur district & 7 & 113 & 193 & 142 \\
\hline
\end{tabular}

Table 3.2 shows that the number of interviewed farmers in Badarganj, Gangachara, Kaunia, Mithapukur, Pirgachha, Pirganj, Rangpur Metro \& Sadar and Taraganj were equally distributed among the sub-districts, although Rangpur Metro \& Sadar have twice as much farmers and are treated as one sub-district. Three interviewed farmers were female (Gangachara, Mithapukur, Pirganj), all others were male.

Table 3.2 also shows the minimum, average and maximum land area with potato, in decimals and hectares. Pirgachha sub-district has the largest average land size (6.7 ha), Pirganj the smallest (0.7 
ha). The maximum area with potatoes was 30,000 decimals, which is 121 ha. Two entries of this magnitude were recorded, one with variety Diamant and one with Asterix. The data on these large areas however, need to be treated with care, as the standard area owned by farmers for temporal crops (including potatoes) is on average much smaller, less than one ha (Bangladesh Bureau of Statistics (BBS) 2013).

Table 3.2 Total area cultivated with potatoes of each sub-district and number of interviewed farmers per sub-district.

\begin{tabular}{|c|c|c|c|c|c|c|c|}
\hline \multirow[b]{2}{*}{ sub-district } & \multirow[b]{2}{*}{ \# farmers } & \multicolumn{3}{|c|}{ Land size (decimal) } & \multicolumn{3}{|c|}{ Land size (ha) } \\
\hline & & Minimum & Average & Maximum & Minimum & Average & Maximum \\
\hline Badarganj & 50 & 50 & 188 & 2,500 & 0.20 & 0.8 & 10 \\
\hline Gangachara & 55 & 60 & 501 & 2,310 & 0.24 & 2.0 & 9 \\
\hline Kaunia & 50 & 25 & 681 & 14,400 & 0.10 & 2.8 & 58 \\
\hline Mithapukur & 50 & 10 & 474 & 4,000 & 0.04 & 1.9 & 16 \\
\hline Pirgachha & 52 & 2 & 1,666 & 30,000 & 0.01 & 6.7 & 121 \\
\hline Pirganj & 50 & 50 & 185 & 700 & 0.20 & 0.7 & 3 \\
\hline Rangpur Metro \& Sadar & 98 & 50 & 636 & 13,500 & 0.20 & 2.6 & 55 \\
\hline Taraganj & 50 & 18 & 607 & 3,750 & 0.07 & 2.5 & 15 \\
\hline Rangpur district & 455 & 2 & 623 & 30,000 & 0.01 & 2.5 & 121 \\
\hline
\end{tabular}

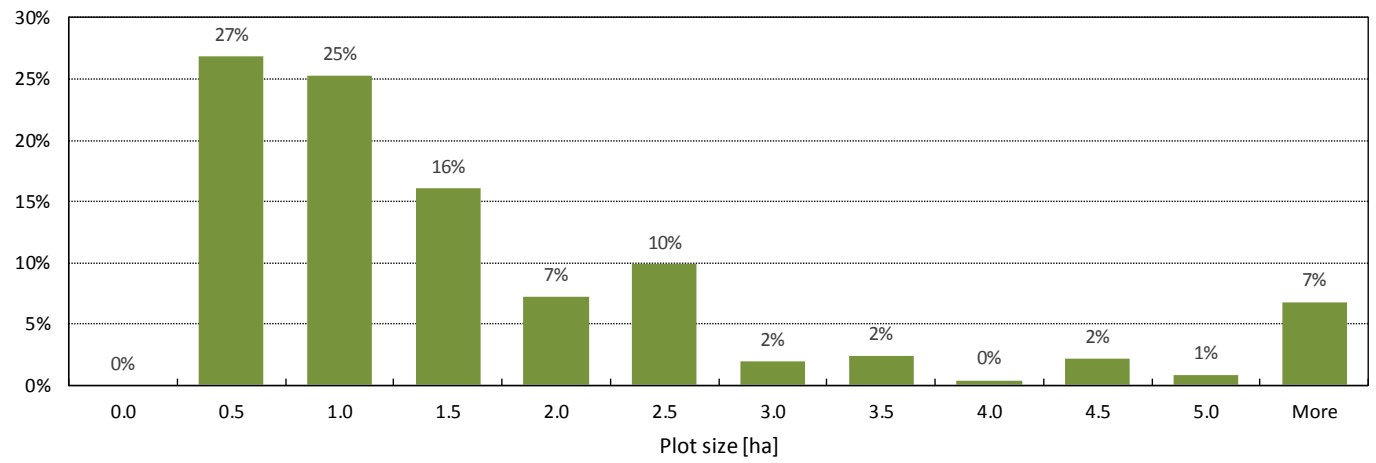

Figure $3.3 \quad$ Frequency distribution of the plot sizes planted with potato in Rangpur.

Almost all farmers grow paddy rice additionally to potatoes. Three farmers grow Chilli, two grow Black gram (black lentil; Vigna mungo L.) and one grows Radish. All non-rice side crops were grown in Badarganj except for Radish that was grown in Rangpur Metro \& Sadar.

\subsubsection{Planting}

Table 3.3 gives an overview of the used potato varieties by the interviewed farmers. Commonly used varieties are Diamant, Cardinal, Asterix and Granola (>15\%), less common are Kufrisinduri, Laura, Meridian and other varieties ( $<15 \%)$. All varieties used were the so called High Yielding Varieties 
(HYV) (Kawochar et al. 2014). More than $90 \%$ of the area planted was with HYV in the potato season of 2016-2017 (Anonymous 2017).

Table 3.3 Number of potato varieties used in Rangpur and its sub-districts by interviewed farmers.

\begin{tabular}{lllllllll}
\hline & \multicolumn{7}{c}{ Name of potato variety } \\
\cline { 2 - 9 } Sub-district & Diamant & Cardinal & Asterix & Granola & Kufrisinduri & Laura & Meridian & Others \\
\hline Badarganj & 1 & 12 & 10 & 21 & 6 & 0 & 0 & 0 \\
Gangachara & 12 & 8 & 2 & 27 & 0 & 3 & 0 & 3 \\
Kaunia & 13 & 26 & 4 & 5 & 1 & 0 & 0 & 1 \\
Mithapukur & 23 & 17 & 1 & 2 & 0 & 5 & 1 & 1 \\
Pirgachha & 11 & 20 & 20 & 0 & 0 & 1 & 0 & 0 \\
Pirganj & 5 & 13 & 0 & 0 & 13 & 0 & 18 & 1 \\
Rangpur Metro \& Sadar & 17 & 27 & 7 & 41 & 0 & 1 & 0 & 5 \\
Taraganj & 2 & 14 & 26 & 3 & 0 & 0 & 0 & 5 \\
\hline Rangpur district & 84 & 137 & 70 & 99 & 20 & 10 & 19 & 16 \\
\hline
\end{tabular}

Table 3.4 gives an overview of the number of farmers that used an authorized dealer as seed source and those that used farm-saved seed. On slightly more than half of the farms (54\%), the seed source is from an authorized dealer. Another large percentage of seeds comes from farm-saved seed. A small percentage is received from an unauthorized dealer.

Table 3.4 Overview of seed source and percentage of total bought as the seed source.

\begin{tabular}{llll}
\hline Sub-district & Authorized dealer & Farm-saved seed & Unauthorized dealer \\
\hline Badarganj & 7 & 40 & 3 \\
Gangachara & 22 & 23 & 10 \\
Kaunia & 14 & 26 & 10 \\
Mithapukur & 42 & 8 & 0 \\
Pirgachha & 26 & 18 & 8 \\
Pirganj & 50 & 0 & 0 \\
Rangpur Metro \& Sadar & 54 & 44 & 0 \\
Taraganj & 29 & 21 & 0 \\
\hline Rangpur district & $244(54 \%)$ & 180 & 31 \\
\hline
\end{tabular}

Table 3.5 gives an overview of the earliest, average and latest planting date in the 2016/17 growing season. All potato seeds were cut before planting and not further treated with a pesticide. Figure 3.3 shows the weekly frequency distribution of planting dates and indicates that more than $75 \%$ of the potato fields were planted in November. 
Table 3.5 Overview of earliest, average and latest planting date in Rangpur and its sub-districts in the 2016/17 growing season.

\begin{tabular}{|c|c|c|c|}
\hline \multirow[b]{2}{*}{ Sub-district } & \multicolumn{3}{|c|}{ Planting date } \\
\hline & Earliest & Average & Latest \\
\hline Badarganj & 18 -Oct & 19-Nov & 05-Dec \\
\hline Gangachara & 28 -Oct & 22-Nov & 20-Dec \\
\hline Kaunia & 05-Nov & 19-Nov & 05-Dec \\
\hline Mithapukur & 23-Oct & 13-Nov & 17-Dec \\
\hline Pirgachha & 05-Nov & 18-Nov & 11-Dec \\
\hline Pirganj & 02-Nov & 07-Nov & 20-Nov \\
\hline Rangpur Metro \& Sadar & 08-Oct & 10-Nov & 03-Dec \\
\hline Taraganj & 29-Oct & 24-Nov & 31-Dec \\
\hline Average & 08-Oct & $16-\mathrm{Nov}$ & 31-Dec \\
\hline
\end{tabular}

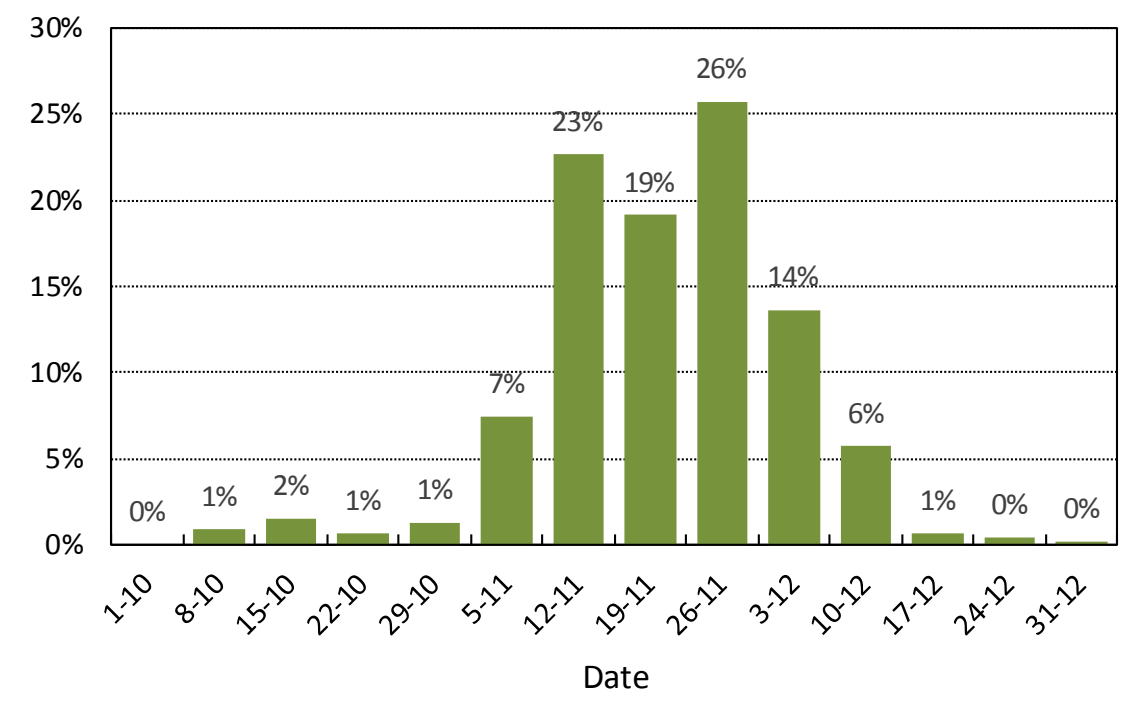

Figure 3.4 Weekly frequency distribution of the potato planting dates in Rangpur in the 2016/17 season.

Table 3.6 gives an overview of the minimum, average and maximum row and intra-row distance and the calculated plant density. 
Table 3.6 Minimum ( $\min )$, average (avg) and maximum (max) row and intra-row distance ( $\mathrm{cm})$, and the calculated plant density (plants/ha).

\begin{tabular}{|c|c|c|c|c|c|c|c|c|c|}
\hline \multirow[b]{2}{*}{ Sub-district } & \multicolumn{3}{|c|}{ Row distance } & \multicolumn{3}{|c|}{ Intra-row distance } & \multicolumn{3}{|c|}{ Plant density } \\
\hline & Min & Avg & $\operatorname{Max}$ & Min & Avg & $\operatorname{Max}$ & Min & Avg & Max \\
\hline Badarganj & 15 & 20 & 22 & 45 & 53 & 55 & 82,645 & 94,682 & 138,889 \\
\hline Gangachara & 13 & 19 & 25 & 40 & 50 & 54 & 74,074 & 104,841 & 167,224 \\
\hline Kaunia & 10 & 17 & 20 & 42 & 48 & 55 & 100,000 & 127,366 & 200,000 \\
\hline Mithapukur & 12 & 14 & 19 & 40 & 51 & 60 & 92,593 & 140,796 & 185,185 \\
\hline Pirgachha & 13 & 16 & 22 & 44 & 52 & 62 & 90,744 & 119,927 & 162,338 \\
\hline Pirganj & 10 & 13 & 14 & 40 & 49 & 52 & 137,363 & 164,694 & 208,333 \\
\hline Rangpur Metro \& Sadar & 7 & 14 & 24 & 18 & 46 & 54 & 84,175 & 173,484 & 793,651 \\
\hline Taraganj & 12 & 13 & 15 & 18 & 51 & 57 & 128,205 & 153,748 & 427,350 \\
\hline Rangpur district & 7 & 16 & 25 & 18 & 50 & 62 & 74,074 & 138,611 & 793,651 \\
\hline
\end{tabular}

\subsubsection{Fertilisation}

Table 3.7 shows the minimum, average and maximum doses of applied urea and TSP fertiliser. The application doses have been converted to hectares instead of acres to comply with the questionnaire. The minimum, average and maximum applied amounts of urea and TSP have also been converted into the amounts of applied $\mathrm{N}$ and $\mathrm{P}_{2} \mathrm{O}_{5}$ at district level, respectively.

The advised doses of fertilisers for potato in Bangladesh for a yield goal of 30 tons/ha for nitrogen are 91 to 135 or 136 to $180 \mathrm{~N} \mathrm{~kg} / \mathrm{ha}$; for phosphate $\approx 50$ to -70 or 71 to $92 \mathrm{P}_{2} \mathrm{O}_{5} \mathrm{~kg} / \mathrm{ha}$ and for potassium $\approx 110$ to 163 or 164 to $217 \mathrm{~K}_{2} \mathrm{O} \mathrm{kg} / \mathrm{ha}$ (FRG 2012) (Annex I). The first (lower) range relates to soils with a 'very low' status according to the soil analysis interpretation. The second (higher) range relates to soils with a 'low' status according to the soil analysis interpretation. From Table 3.7 it becomes clear that the current average application rates for $\mathrm{N}(177 \mathrm{~kg} / \mathrm{ha})$ is in line with the recommendation for "very low" and $\mathrm{P}_{2} \mathrm{O}_{5}(174 \mathrm{~kg} / \mathrm{ha}$ or $\approx 60 \mathrm{~kg} \mathrm{P} / \mathrm{ha})$ is higher than the recommendation. 
Table 3.7 Minimum, average and maximum applied urea and triple superphosphate (TSP, $\mathrm{kg} / \mathrm{ha}$ ) in Rangpur district and its sub-districts, and the minimum, average and maximum applied $\mathrm{N}$ and $\mathrm{P}_{2} \mathrm{O}_{5}(\mathrm{~kg} / \mathrm{ha})$ in Rangpur.

\begin{tabular}{|c|c|c|c|c|c|c|}
\hline \multirow[b]{2}{*}{ Sub-district } & \multicolumn{3}{|c|}{ Urea (kg/ha) } & \multicolumn{3}{|c|}{ TPS (kg/ha) } \\
\hline & Minimum & Average & Maximum & Minimum & Average & Maximum \\
\hline Badarganj & 185 & 273 & 433 & 124 & 226 & 433 \\
\hline Gangachara & 247 & 433 & 1,236 & 247 & 454 & 741 \\
\hline Kaunia & 346 & 487 & 989 & 247 & 407 & 618 \\
\hline Mithapukur & 247 & 420 & 618 & 247 & 465 & 741 \\
\hline Pirgachha & 371 & 506 & 989 & 198 & 393 & 519 \\
\hline Pirganj & 74 & 263 & 494 & 0 & 432 & 989 \\
\hline Rangpur Metro \& Sadar & 185 & 320 & 494 & 247 & 404 & 1,236 \\
\hline Taraganj & 124 & 432 & 618 & 124 & 283 & 989 \\
\hline Rangpur district & 74 & 385 & 1,236 & 0 & 386 & 1,236 \\
\hline Average kg N or $\mathrm{P}_{2} \mathrm{O}_{5} /$ ha & 34 & 177 & 568 & 0 & 174 & 556 \\
\hline
\end{tabular}

\subsubsection{Production}

Table 3.8 shows the harvest time and number of growing days, i.e. the difference between harvest and planting date. Figure 3.5 shows the weekly frequency distribution of harvesting dates.

Table 3.8 Minimum, average and maximum harvest time and number of growing days in Rangpur and its sub-districts.

\begin{tabular}{|c|c|c|c|c|c|c|}
\hline \multirow[b]{2}{*}{ Sub-district } & \multicolumn{3}{|c|}{ Harvest date } & \multicolumn{3}{|c|}{ Number of growing days } \\
\hline & Minimum & Average & Maximum & Minimum & Average & Maximum \\
\hline Badarganj & 10 January & 23 February & 14 March & 64 & 96 & 119 \\
\hline Gangachara & 05 January & 26 February & 27 March & 66 & 96 & 136 \\
\hline Kaunia & 15 January & 24 February & 25 March & 60 & 97 & 123 \\
\hline Mithapukur & 08 January & 14 February & 26 March & 61 & 93 & 124 \\
\hline Pirgachha & 10 February & 24 February & 14 March & 88 & 98 & 126 \\
\hline Pirganj & 09 January & 10 February & 28 February & 61 & 94 & 117 \\
\hline Rangpur Metro \& Sadar & 02 January & 28 January & 15 March & 45 & 79 & 122 \\
\hline Taraganj & 01 February & 23 February & 27 March & 64 & 91 & 126 \\
\hline Rangpur district & 02 January & 16 February & 27 March & 45 & 92 & 136 \\
\hline
\end{tabular}




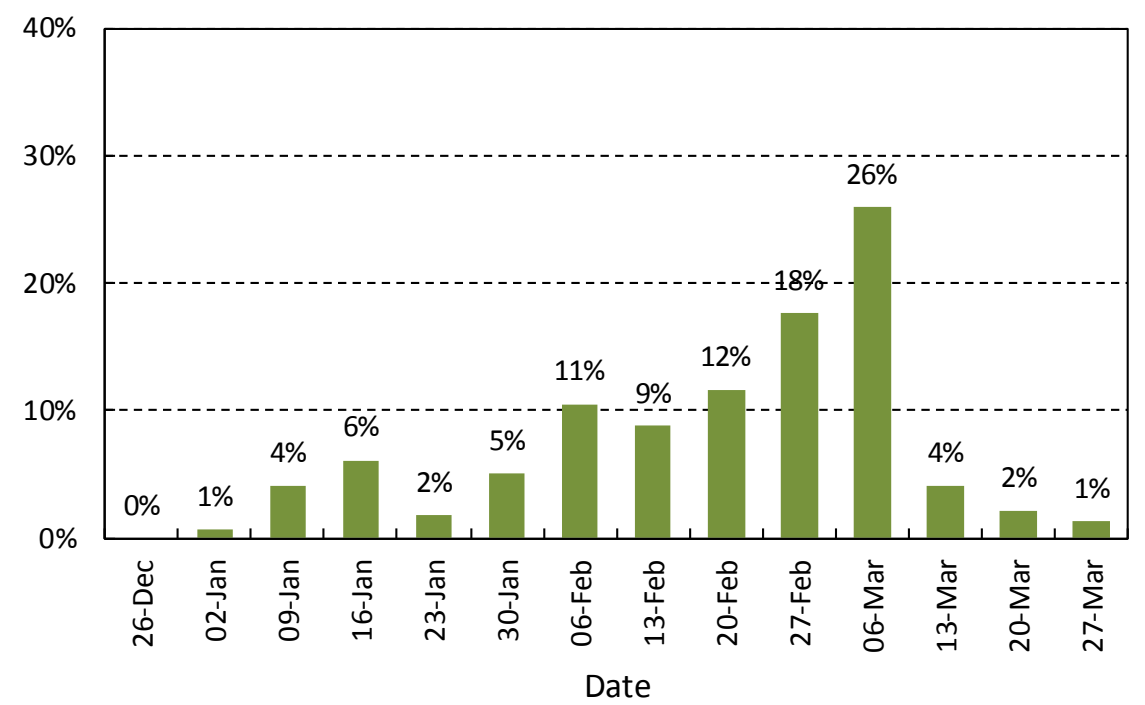

Figure 3.5 Weekly frequency distribution of the harvesting date in Rangpur in the 2016/17 season.

Figure 3.6 shows the five-day frequency distribution of the length of the growing period in Rangpur in the 2016/17 season. The majority of farmers needed between 90 and 100 growing days for completion of potato growth.

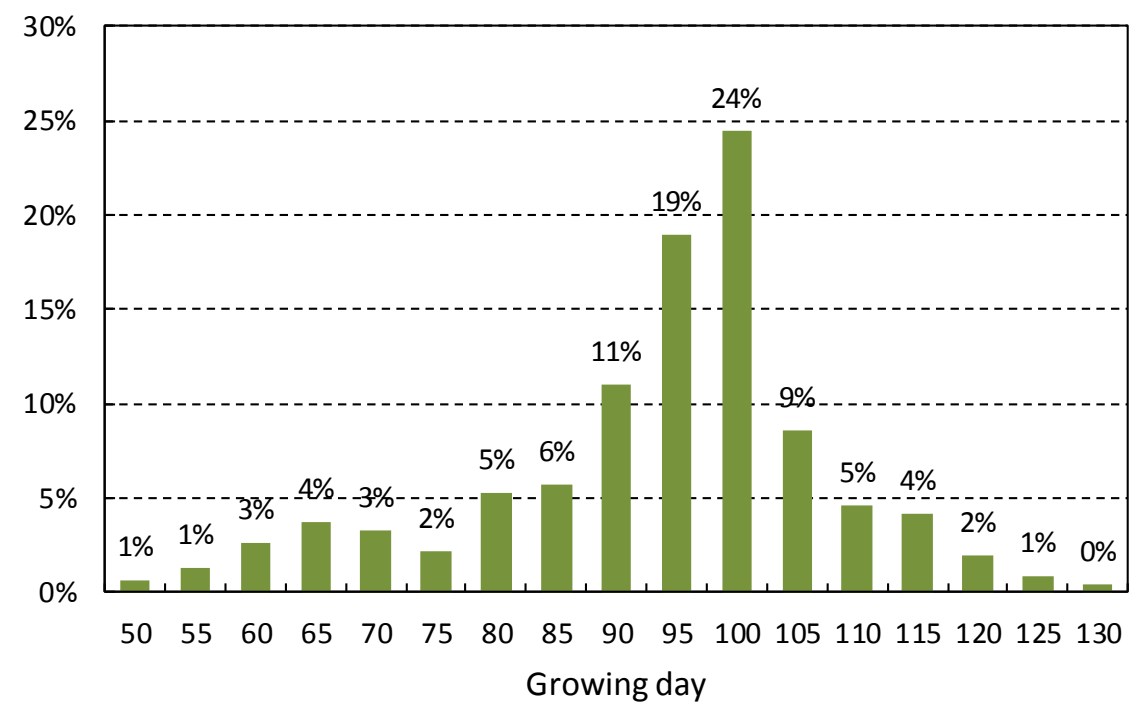

Figure 3.6 The five-day frequency distribution of the growing period of potatoes in Rangpur in the season 2016/17.

The potato yields varied between 3.7 and 43.7 tonnes/ha (Table 3.9) with an average yield of 25 tonnes/ha. This yield is considerably higher than the national average of only 20 tonnes/ha and of the average yields found in the Rangpur division of also 20 tonnes/ha (Figure 1.3), but lower than 
found in the baseline study for Munshiganj district (Pronk et al. 2017). Yields differed between subdistricts and was not related to the use of different fungicide products (Table 3.9).

Table $3.9 \quad$ Potato yields (in tonnes/ha) in Rangpur and its sub-districts in the 2016/17 season.

\begin{tabular}{llll}
\hline Sub-district & Minimum & Average & Maximum \\
\hline Badarganj & 14.8 & 23.0 & 32.1 \\
Gangachara & 14.8 & 26.5 & 43.7 \\
Kaunia & 3.7 & 28.0 & 39.5 \\
Mithapukur & 7.4 & 21.1 & 32.1 \\
Pirgachha & 19.8 & 28.8 & 39.5 \\
Pirganj & 18.5 & 22.7 & 29.7 \\
Rangpur Metro \& Sadar & 14.8 & 25.2 & 37.1 \\
Taraganj & 11.4 & 24.3 & 30.4 \\
\hline Rangpur district & 3.7 & 25.0 & 43.7 \\
\hline Sub-district & & $* * *$ & \\
Type of active ingredients & & n.s. & \\
Sub-district * Type of active ingredient & & n.s. & \\
\hline
\end{tabular}

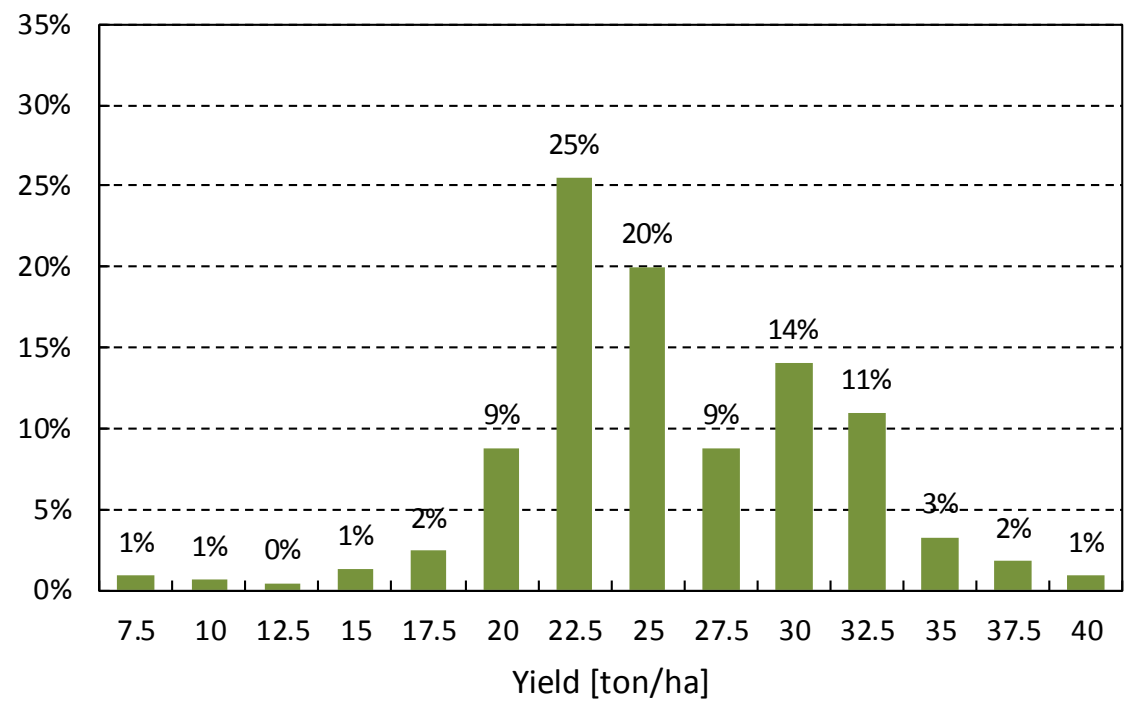

Figure 3.7 Frequency distribution of potato yields in Rangpur. 

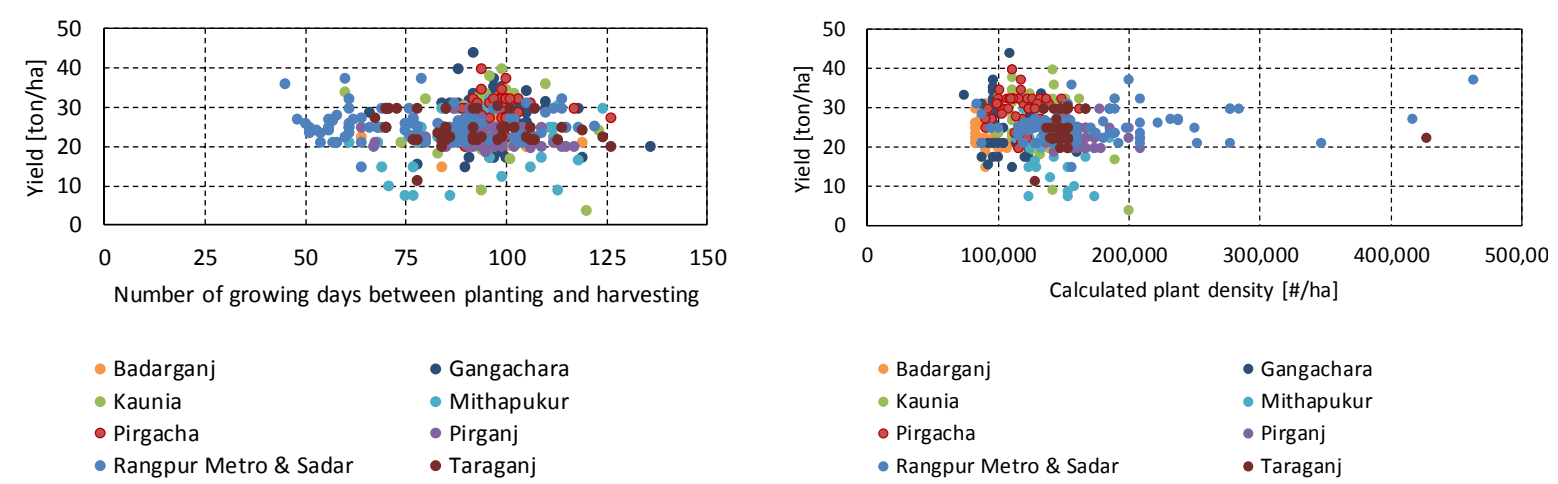

Figure 3.8 Relationship between the number of growing days (left) and the calculated plant density (plants/ha, right) and potato yield.

Because of the variation in length of growing period (Table 3.8) in theory one would expect a relationship between length of growing period and yield, i.e. higher yields with longer growing periods. However, Figure 3.8 (left) shows that there is no relationship between the number of growing days and potato yield. This relationship may not be found as the day of harvest is not the day dry mass productions ends, the so-called haulm-killing day. Depending on practical issues, time between haulm killing and harvest differs between farmers. In addition, sometimes crops die due to late blight infections and the day the dry mass production ends is difficult to indicate.

Because of the high variation in planting density (Table 3.6), we also studied the relationship between plant density and yield (Figure 3.8, right). This plant density - yield relationship however, did not show a clear trend either.

Table 3.10 shows the price at which farmers sold their potatoes after the harvest. The price varied between $1,000 \mathrm{BDT} /$ ton to a maximum of $12,000 \mathrm{BDT} / \mathrm{ton}$. The average sales price was $8,431 \mathrm{BDT} /$ ton potatoes which is lower than the harvest time market price of potatoes during the past seven years (Figure 3.9).

Table $3.10 \quad$ Sales prices of potatoes (BDT/ton).

\begin{tabular}{llcc}
\hline Sub-district & Minimum & Average & Maximum \\
\hline Mithapukur & 7,000 & 9,860 & 12,000 \\
Pirgachha & 8,000 & 8,981 & 12,000 \\
Taraganj & 8,000 & 9,400 & 17,000 \\
Gangachara & 1,000 & 7,432 & 12,000 \\
Pirganj & 8,000 & 10,200 & 12,000 \\
Badarganj & 5,000 & 6,990 & 9,000 \\
Kaunia & 5,000 & 8,020 & 12,000 \\
Rangpur Metro \& Sadar & 5,000 & 7,518 & 12,000 \\
\hline Rangpur district & 1,000 & 8,431 & 12,000 \\
\hline
\end{tabular}




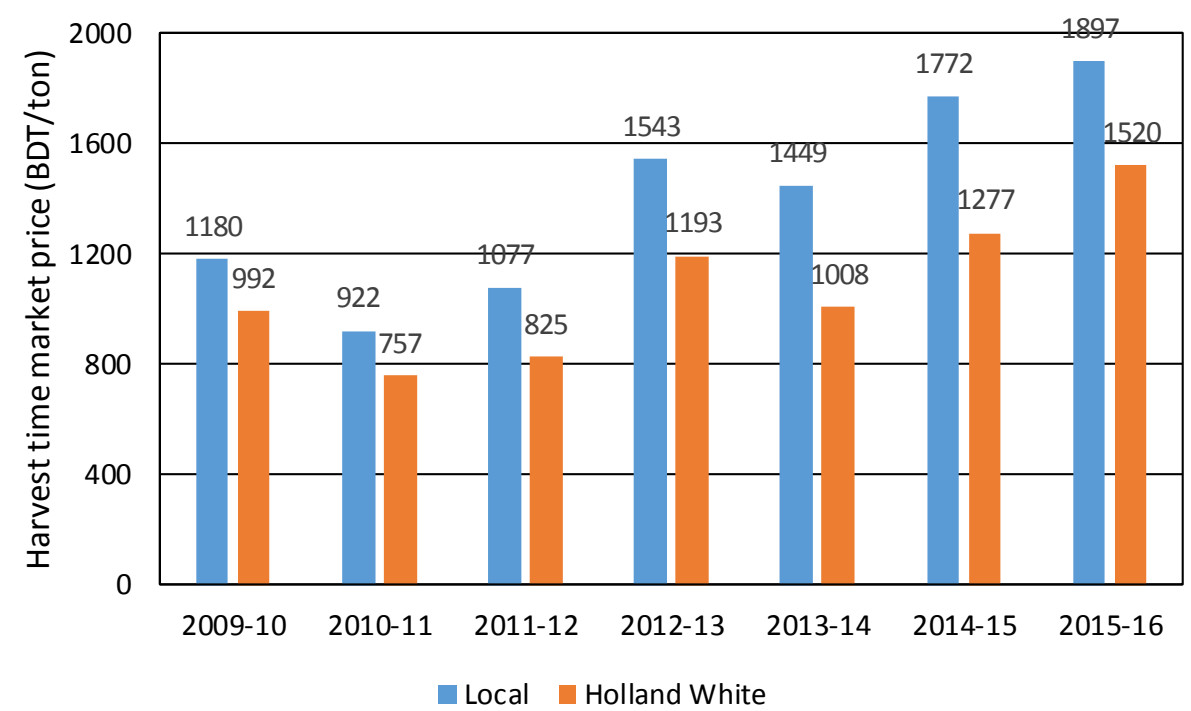

Figure 3.9 The harvest time market price of local potatoes and 'Holland White' of the past seven years (Bangladesh Bureau of Statistics (BBS) 2013; 2016).

\subsubsection{Control of late blight}

Almost half of the farmers, $43 \%$, indicated that the late blight pressure was medium (Table 3.11), $20 \%$ said that late blight pressure was high and $37 \%$ experienced a low late blight pressure. There was a difference between sub-districts in late blight pressure according to farmers $(p<0.001)$ : late blight pressure was indicated to be higher in Gangachara, Pirganj and Rangpur Metro \& Sadar compared to the other sub-districts. The lowest pressure was indicated in Pirganj.

Table 3.11 The late blight pressure according to farmers (\#; \%) in Rangpur and its sub-districts.

\begin{tabular}{|c|c|c|c|c|c|c|}
\hline \multirow[b]{2}{*}{ Sub-district } & \multicolumn{2}{|c|}{ Low } & \multicolumn{2}{|c|}{ Medium } & \multicolumn{2}{|c|}{ High } \\
\hline & $\#$ & $\%$ & $\#$ & $\%$ & $\#$ & $\%$ \\
\hline Badarganj & 26 & 52 & 19 & 38 & 5 & 10 \\
\hline Gangachara & 13 & 24 & 21 & 38 & 21 & 38 \\
\hline Kaunia & 19 & 38 & 25 & 50 & 6 & 12 \\
\hline Mithapukur & 26 & 52 & 16 & 32 & 8 & 16 \\
\hline Pirgachha & 37 & 71 & 9 & 17 & 6 & 12 \\
\hline Pirganj & 3 & 6 & 33 & 66 & 14 & 28 \\
\hline Rangpur Metro \& Sadar & 21 & 21 & 47 & 48 & 30 & 31 \\
\hline Taraganj & 24 & 48 & 26 & 52 & 0 & 0 \\
\hline Rangpur district & 169 & 37 & 196 & 43 & 90 & 20 \\
\hline
\end{tabular}

On average farmers start late blight control 45 days after planting (Table 3.12). Because the growing season is on average 92 days, farmers apply on average nine applications with an application interval of 8 days. 
Table 3.12 The minimum ( $\mathrm{min}$ ), average (avg) and maximum ( $\max$ ) number of days after planting (DAP) that late blight was observed by farmers, the number of fungicide applications per season (times per season) and the application interval time (days) for the different sub-districts and Rangpur district, and the results of the statistical analysis.

\begin{tabular}{|c|c|c|c|c|c|c|c|c|c|}
\hline \multirow[b]{2}{*}{ Sub-district } & \multicolumn{3}{|c|}{ DAP } & \multicolumn{3}{|c|}{ \# of applications } & \multicolumn{3}{|c|}{ Application Interval } \\
\hline & $\min$ & avg & $\max$ & $\min$ & avg & $\max$ & $\min$ & avg & $\max$ \\
\hline Badarganj & 27 & 49 & 77 & 2 & 7 & 12 & 2 & 7 & 11 \\
\hline Gangachara & 22 & 43 & 76 & 4 & 9 & 17 & 2 & 10 & 19 \\
\hline Kaunia & 28 & 53 & 85 & 4 & 11 & 18 & 1 & 5 & 12 \\
\hline Mithapukur & 27 & 50 & 76 & 1 & 7 & 12 & 2 & 7 & 12 \\
\hline Pirgachha & 11 & 41 & 89 & 3 & 9 & 12 & 2 & 10 & 19 \\
\hline Pirganj & 29 & 41 & 74 & 5 & 11 & 27 & 4 & 11 & 26 \\
\hline Rangpur Metro \& Sadar & 23 & 44 & 77 & 3 & 7 & 15 & 0 & 7 & 19 \\
\hline Taraganj & 0 & 38 & 90 & 4 & 11 & 20 & 2 & 9 & 23 \\
\hline Rangpur district & 0 & 45 & 90 & 1 & 9 & 27 & 0 & 8 & 26 \\
\hline Sub-district & & $* * *$ & & & $* * *$ & & & $* * *$ & \\
\hline Type of active ingredients & & n.s. & & & n.s. & & & n.s. & \\
\hline Sub-district * Type of active ingredients & & n.s. & & & n.s. & & & n.s. & \\
\hline
\end{tabular}

Table 3.13 The average day that late blight (LB) was first observed, the average day the first fungicide spray was applied and the percentage of farmers that applied the first spray after LB was observed.

\begin{tabular}{llll}
\hline Sub-district & LB was first observed & First fungicide spray & \% farmers first spray after LB observed \\
\hline Badarganj & $07 / \mathrm{Jan} / 17$ & $04 / \mathrm{Jan} / 17$ & 10 \\
Gangachara & $02 / \mathrm{Jan} / 17$ & $26 / \mathrm{Dec} / 16$ & 9 \\
Kaunia & 29/Dec/16 & $28 / \mathrm{Dec} / 16$ & 2 \\
Mithapukur & $18 / \mathrm{Dec} / 16$ & $17 / \mathrm{Dec} / 16$ & 6 \\
Pirgachha & $24 / \mathrm{Dec} / 16$ & $22 / \mathrm{Dec} / 16$ & 2 \\
Pirganj & $01 / \mathrm{Jan} / 17$ & $26 / \mathrm{Dec} / 16$ & 8 \\
Rangpur Metro \& Sadar & $01 / \mathrm{Jan} / 17$ & $28 / \mathrm{Dec} / 16$ & 17 \\
Taraganj & $01 / \mathrm{Jan} / 17$ & 26/Dec/16 & 16 \\
\hline Rangpur district & 01/Jan/17 & 28/Dec/16 & 10 \\
\hline
\end{tabular}

In total there are 217 fungicides registered in Bangladesh for late blight control in potato. Of these 217 products, 92 were mentioned by farmers to be used, which is $42 \%$ of all available products. Not all products have the ability to control late blight. Some are not suitable, such as Bismerthiazol, some have only very limited effects, such as copper containing products and some have no effect as late blight is resistant to the chemical compound, such as Metalaxyl and Benalaxyl. 
Table 3.14 The number and percentage of farmers that mentioned to use a specific fungicide active ingredient of total recordings and the type of active ingredient.

\begin{tabular}{llll}
\hline Active ingredient & $\begin{array}{l}\text { Number of } \\
\text { recordings }\end{array}$ & $\begin{array}{l}\text { \% of total } \\
\text { recordings }\end{array}$ & type of fungicide \\
\hline Bismerthiazol & 5.0 & 2.5 & No late blight \\
Chlorothalonil & 0.7 & 0.3 & Preventive \\
Copper hydroxide & 2.8 & 1.4 & Preventive \\
Copper oxychloride (50\%) Copper & 0.3 & 0.1 & Preventive \\
oxychloride (50\%) & & & \\
Dimethomorph (9\%) + Mancozeb (60\%) & 36.5 & 18.3 & Preventive + curative \\
Mancozeb & 4.2 & 2.1 & Preventive \\
Mancozeb (12\%) + Copper (30\%) & 1.0 & 0.5 & Preventive \\
Mancozeb (50\%) + Fenamidone (10\%) & 58.5 & 29.3 & Preventive \\
Mancozeb (63\%) + Carbendazim (12\%) & 1.5 & 0.7 & Preventive \\
Mancozeb (64\%) + Benalaxyl (8\%) & 9.0 & 4.5 & Preventive + curative resistance \\
Mancozeb (64\%) + Cymoxanil (8\%) & 0.5 & 0.3 & Preventive + curative \\
Mancozeb (64\%) + Metalaxyl (4\%) & 2.4 & 1.2 & Preventive + curative resistance \\
Mancozeb (64\%) + Metalaxyl (8\%) & 1.5 & 0.8 & Preventive + curative resistance \\
Mandipromid & 13.0 & 6.5 & Preventive \\
Metalaxyl & 14.7 & 7.4 & Curative resistance \\
Phosphorous Acid & 5.0 & 2.5 & Preventive \\
Propineb & 7.5 & 3.8 & Preventive \\
Propineb (70\%) + Cymoxanil (6\%) & 1.0 & 0.5 & Preventive + curative \\
Propineb (70\%) + Iprovalicarb & 29.0 & 14.5 & Preventive + slightly curative \\
Zineb & 5.3 & 2.7 & Preventive \\
\hline Total number of recordings & 199 & & \\
\hline & & & \\
\hline
\end{tabular}

In Rangpur, farmers said only to use knapsacks for the application of fungicides.

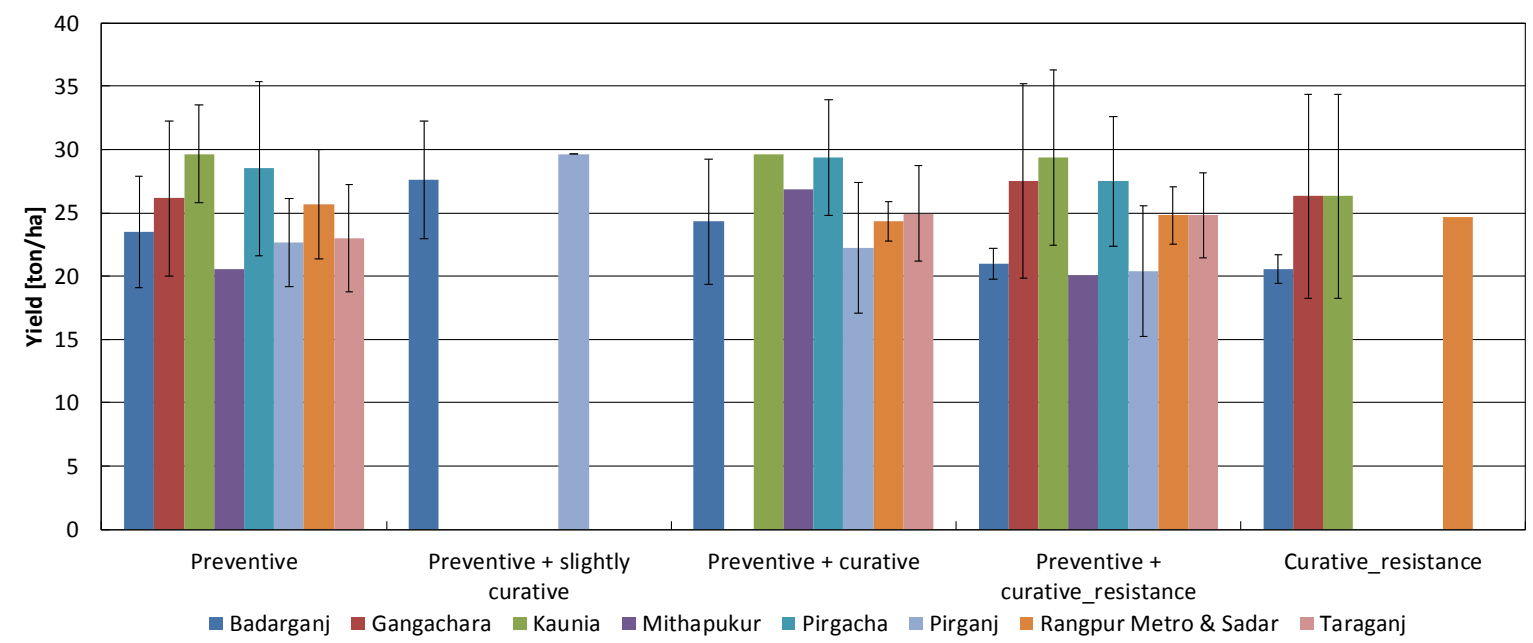

Figure 3.10 The effect of different types of active ingredients on yield of the interviewed farmers in different sub-districts. 


\subsection{Baseline outcome indicators}

The outcome indicators for the baseline survey are summarized in Table 3.15 and Table 3.16. The subsequent indicators are evaluated and compared with the outcome indicators found in the baseline study of Munshiganj (Pronk et al. 2017).

\section{Improvement in sustainable food production}

The average yield in Rangpur was 25 tons/ha (Table 3.9) which was considerable lower than the average yield of 31 tons/ha found in the baseline study of Munshiganj (Pronk et al. 2017).

\section{Improvement in resource use efficiency}

The fertiliser use efficiency of farmers in Rangpur varied between 5.6 and $10.8 \mathrm{~kg} \mathrm{~N}$ per ton potatoes produced and was $7.5 \mathrm{~kg} \mathrm{~N} /$ ton on average (Table 3.15). This value is somewhat lower than the $\mathrm{N}$-use efficiency of farmers of $8.9 \mathrm{~kg} \mathrm{~N} /$ ton in the baseline study of Munshiganj (Pronk et al. 2017).

The fungicide use efficiency expressed as kg product/ha varied between 9 and $14.3 \mathrm{~kg}$ product per ha and was $11.4 \mathrm{~kg} / \mathrm{ha}$ on average (Table 3.15). This value is substantially higher than the $7.7 \mathrm{~kg}$ product/ha found in the baseline study of Munshiganj (Pronk et al. 2017). Additionally, the use of $\mathrm{kg}$ A.I./ha was also higher, $8.3 \mathrm{~kg} \mathrm{A.I./ha} \mathrm{in} \mathrm{Rangpur} \mathrm{compared} \mathrm{to} 5.6 \mathrm{~kg} \mathrm{A.I./ha} \mathrm{in} \mathrm{the} \mathrm{baseline} \mathrm{study} \mathrm{of}$ Munshiganj.

Table 3.15 Baseline outcome indicators, $\mathrm{N}$-use efficiency and fungicide use efficiency, of farmers in Rangpur and its sub-districts.

\begin{tabular}{|c|c|c|c|}
\hline \multirow[b]{2}{*}{ Sub-district } & \multirow{2}{*}{$\begin{array}{l}\mathrm{N} \text {-fertiliser use } \\
\mathrm{kg} \mathrm{N} / \text { ton product }\end{array}$} & \multicolumn{2}{|c|}{ Fungicide use } \\
\hline & & $\mathrm{kg}$ product/ha & kg A.I./ha \\
\hline Badarganj & 5.6 & 10.8 & 7.8 \\
\hline Gangachara & 8.2 & 12.6 & 9.7 \\
\hline Kaunia & 9.3 & 11.6 & 7.6 \\
\hline Mithapukur & 10.8 & 9.6 & 7.2 \\
\hline Pirgachha & 8.3 & 14.3 & 10.7 \\
\hline Pirganj & 5.4 & 14.0 & 10.7 \\
\hline Rangpur Metro \& Sadar & 5.9 & 9.0 & 6.5 \\
\hline Taraganj & 8.2 & 11.1 & 8.1 \\
\hline Rangpur district & 7.5 & 11.4 & 8.3 \\
\hline
\end{tabular}

\section{Improvement in income}

Improvement in income was not calculated as the prices of fungicide products (125 different products in total) was not asked in the questionnaire. The costs of fungicide applications in the base line situation and subsequently the cost price per unit of product as indicator of income will be calculated in a later phase of the project. 


\section{Other outcomes}

The number of fungicide products with curative active ingredients mentioned to be used by farmers is shown in Table 3.16. More than $80 \%$ of these products contained Metalaxyl.

The average number of applications per farmer with products containing curative active ingredients was 4.3 and ranged from 3.6 to 6.3 (Table 3.16). Of these 4.3 applications, 2.4 applications (or 55\%) contained Metalaxyl. In Kaunia, $93 \%$ of the fungicide sprays with curative active ingredients were with Metalaxyl followed by $84 \%$ in Gangachara and $76 \%$ in Mithapukur. In Pirgachha and Pirganj most curative applications per farmer were applied, 6.3 and 4.9 applications, respectively. These applications were, however, with fungicides that had other curative active ingredients than Metalaxyl, only $20 \%$ contained Metalaxyl. In other words, the fungicide applications that had a curative effect on late blight.

Table 3.16 Baseline values for outcome evaluation for fungicide products with curative active ingredients (Products, \#) or Metalaxyl (\#; \%) and applications with products with curative active ingredients (Applications; \#) or Metalaxyl (\#; \%) of the farmers in Rangpur and its sub-districts.

\begin{tabular}{|c|c|c|c|c|c|c|}
\hline \multirow[b]{2}{*}{ Sub-district } & \multirow{2}{*}{$\begin{array}{l}\text { Products } \\
\#\end{array}$} & \multicolumn{2}{|c|}{ Metalaxyl } & \multirow{2}{*}{$\begin{array}{l}\text { Applications } \\
\#\end{array}$} & \multicolumn{2}{|c|}{ Metalaxyl } \\
\hline & & $\#$ & $\%$ & & $\#$ & $\%$ \\
\hline Badarganj & 4 & 2 & 55 & 3.6 & 1.6 & 44 \\
\hline Gangachara & 11 & 8 & 73 & 4.7 & 3.9 & 84 \\
\hline Kaunia & 10 & 7 & 70 & 4.0 & 3.7 & 93 \\
\hline Mithapukur & 12 & 11 & 92 & 4.3 & 3.3 & 76 \\
\hline Pirgachha & 6 & 3 & 50 & 6.3 & 0.6 & 10 \\
\hline Pirganj & 5 & 2 & 40 & 4.9 & 0.9 & 18 \\
\hline Rangpur Metro \& Sadar & 17 & 14 & 82 & 3.8 & 1.7 & 45 \\
\hline Taraganj & 20 & 16 & 80 & 3.9 & 3.0 & 76 \\
\hline Rangpur district & 42 & 34 & 81 & 4.3 & 2.4 & 56 \\
\hline
\end{tabular}




\section{Discussion and conclusions}

\subsection{Discussion}

\section{Methodology}

The baseline study questionnaire for Rangpur has been improved with the finding of the baseline study of Munshiganj, i.e. the formulation of the questions and the number of questions. The questionnaire should not require too much time of the farmer and only provide information needed to assess and understand the information needed for the baseline study.

However, new insights have emerged and registered to be included in the evaluation surveys for Rangpur and Munshiganj to come. The evaluation of the target group's age was not yet included and additional detailed questions are needed to evaluate fungicide application costs. It is an ongoing cycle of improvements and applicability of the survey with respect to needed time for completion and qualified/specialised enumerators on the one hand and information on the other hand. Optimising this balance is key priority and receives constant attention.

The baseline study was performed in between the potato growing seasons and used the farmer's memory to answer questions. This may have had an effect on the accuracy of some answers, especially those related to the time of operations. These answers may have a more general character in the sense of what the farmer is usually doing and less of the specific potato growing season 201617. Hence, these data should be used with care.

The major improvement of this survey compared to the Munshiganj baseline survey was on the use of fungicides. Where this previously was an open question, enumerators now had to choose from a drop down list of 217 registered fungicide products for late blight from the Bangladesh Crop Protection Association (www.bcpabd.com/list-of-pesticide.php). This substantially improved the analysis on the use of active ingredients.

The methodology of asking farmers questions served the purpose of understanding behaviour of farmers, their needs, bottlenecks and barriers of late blight control and provided information on the pesticides/fungicides used. These all support this baseline to be a solid starting point to introduce the late blight alert service.

\section{Selection of farmers}

The selection of farmers was done by the DEA. The intension was to select a representative sample of potato farmers, where cultivated land is an important criteria. The average area cultivated with temperate crops, such as potato, was 0.33 ha in Rangpur in 2008, that is 79,000 farm holdings cultivated 40,563 ha of land with temperate crops (Bangladesh Bureau of Statistics (BBS) 2013). Rabbini (2010) found that the average area in 2009 cultivated with potato in Rangpur was 1.6 ha/farmer, Although average area cultivated per farmer may have increased and potato farmers may have rented additional land on top of their own, the $2.5 \mathrm{ha} /$ farmer found in this baseline (Table 3.2) seems large and indicating that the DEA selection was biased towards larger farmers. The DAE admitted after the surveys were carried out that larger farmers were selected for the survey. In 
general, DAE has more contact with the larger farmers than the farmers that produce potatoes at small plots in Rangpur.

The average area of $2.5 \mathrm{ha} /$ farmer with potato in this baseline survey in Rangpur is smaller than the $3.4 \mathrm{ha} /$ farmer found in the baseline survey of Munshiganj but larger than the $1.6 \mathrm{ha} / \mathrm{farmer}$ for Rangpur found by Rabbani earlier. The total area cultivated with potato in Bangladesh has increased between 2009/10 and 2016/17 which may contribute to increased area's in Rangpur.

\section{Potato production}

The average yield found in the baseline study was 25 tonnes/ha (Table 3.9). This yield was higher than the countries average of 20 tonnes/ha (2016; FAOSTAT) but lower than the yield of 31 tonnes/ha found in the baseline survey for the Munshiganj district (Pronk et al. 2017). The average yield in the Rangpur district was 21 tonnes per ha in 2016 (Agricultural Wing 2017) so yields in this study are found to be slightly higher. The Munshiganj district is known to have high yields which is suggested to be related to the good quality of seed potatoes used by farmers and the awareness of farmers to buy good quality of seed (Hoque \& Sultana 2012).

\section{Control of late blight}

Almost half of the farmers, 43\%, indicated that late blight pressure was medium (Table 3.11), $20 \%$ said that late pressure was high and $37 \%$ experienced a low late blight pressure. Late blight in the Rangpur district is in general a more severe disease compared to the Munshiganj district (Figure 4.1). Severe yield losses occur periodically with high incidences reported in the potato growing season of 2006-2007 when between $50 \%$ to almost $80 \%$ of the yield nationwide was lost (Dey et al. 2010). Field visits of Dutch participants in January 2017 identified late blight infections in all visited fields, which certainly have resulted in yield loss. Rangpur district suffers from mist and "low temperatures", which are extremely suitable conditions for late blight to develop and become epidemic. Most farmers apply the first fungicide spray 45 days after planting. About $10 \%$ of farmers apply the first stray after late blight is observed. The preventive fungicides will not control late blight and when farmers use curative fungicides with the active curative ingredients Metalaxyl or Benalaxyl, late blight is not controlled, as it is resistant to those chemicals. Those farmers are suffering yield losses due to late blight. There are hardly qualified curative fungicides available for farmers in Rangpur and Bangladesh, only the curative active ingredient Cymoxanil is available in combination with preventive active ingredients and the slightly curative active ingredient Iprovalicarb is on the market in combination with the preventive active ingredient Propineb. Our service aims to prevent late blight though timely applications of preventive active ingredients, but occasionally curative active ingredients need to be applied when predictions on late blight incidences were inadequate. After such a curative application, preventive active ingredients are to be used again. However, when the curative application is not working correctly the system fails and farmers may lose faith in the service. Therefore, there is a need for modern curative active ingredients for late blight control in Bangladesh. 
Late blight was observed very early in Mithapukur, on $18^{\text {th }}$ of December and latest on 7 January in Badarganj (Table 3.13). Farmers applied the first spray in general before late blight was observed; only $10 \%$ did spray after late blight was observed. Only in Rangpur Sadar \& Metro, $17 \%$ of the farmers and in Taraganj $16 \%$ of the farmers applied the first spray after late blight was observed (Table 3.13) which is much better than the farmers in Munshiganj where on average $50 \%$ applied the first spray after late blight was observed (Pronk et al. 2017).

The total number of growing days or the estimated number of late blight free growing days did not correlate with yield although one would expect that there is a relationship as a longer and disease free growing would increase yields (Figure 3.8). Early planting, that is before or around 15 November, is found to increase yield (Haque et al. 2013) as the number of late blight free growing days is increased. However, that result is not substantiated with findings of this baseline study.

Figure 4.1 Distribution of late blight disease of potato in Bangladesh (from Dey et al., 2010)

\section{Baseline indicators}

The use efficiency of $\mathrm{N}$-fertilisers in this baseline study ranged from 5.4 to $10.8 \mathrm{~kg} \mathrm{~N} /$ ton potatoes produced (Table 3.15) and was $7.5 \mathrm{~kg} \mathrm{~N} /$ ton on average (Table 4.1). The $\mathrm{N}$ - use efficiency is higher than that of the Munshiganj district, caused by a lower and within the guidelines average $\mathrm{N}$ application of $177 \mathrm{~kg} / \mathrm{ha}$ (Table 3.7) compared to $277 \mathrm{~kg} / \mathrm{ha}$ in the Munshiganj baseline survey (Pronk et al. 2017). However, yields in Rangpur are also lower, 25 tonnes/ha compared to 31 tonnes/ha 
(Table 3.15) but that difference is much smaller than the difference in $\mathrm{N}$-application. When looking at the fertiliser guidelines for a target yield of 30 tonnes/ha at low and very low soil fertility status, the $\mathrm{N}$-use efficiency ranges from 3 to $6 \mathrm{~kg} \mathrm{~N} /$ ha (Table 4.2). This suggests that there is still room for improvement on the $\mathrm{N}$-use efficiency.

The fungicide applications, both expressed in kg product per hectare and in kg A.l. per hectare, were in Rangpur a bit lower than in Munshiganj, but the differences are less than $5 \%$.

The service to be introduced aims at the application of preventive active ingredients mainly and curative active ingredients only when farmers have inadequately followed the advice or when the service had some inaccuracies when weather data were not predicted adequately. When curative active ingredients are to be used they need to control late blight which means that in this region other curative active ingredients than Metalaxyl are needed.

Table 4.1 Baseline values for outcome evaluation of farmers in Munshiganj and Rangpur.

\begin{tabular}{lllll}
\hline Category & Indicator & Unit & Munshiganj & Rangpur \\
\hline $\begin{array}{l}\text { Improvement in sustainable } \\
\text { food production }\end{array}$ & Yield & tonnes/ha & 31 & 25 \\
Improvement in efficiency & N-fertiliser use & kg N/ton product & 8.9 & 7.5 \\
& Fungicide use & kg product/ha & 11.8 & 11.4 \\
Improvement in income & Costs fungicide & kg A.I./ha & 8.6 & 8.3 \\
& BDplications & BDT/kg product & 0.225 & 1 \\
Other outcome & Curative products & \% & 50 & 81 \\
& $\begin{array}{l}\text { with Metalaxyl } \\
\text { Curative applications }\end{array}$ & $\%$ & 78 & 56
\end{tabular}

${ }^{1}$ Will be calculated at a later phase in the project

Table 4.2 The nitrogen fertiliser application recommendations for different soil fertility statuses for a yield goal of 30 tonnes/ha \pm 3.0 tonnes/ha (FRG 2012) and calculated N-fertiliser use efficiency.

\begin{tabular}{lll}
\hline Soil analysis Interpretation & $\mathrm{N}$-application $(\mathrm{kg} / \mathrm{ha})$ & $\mathrm{N}$-fertiliser use efficiency \\
\hline Optimum & $0-45$ & 1.5 \\
Medium & $46-90$ & $1.5-3$ \\
Low & $91-135$ & $3-4.5$ \\
Very low & $136-180$ & $4.5-6$ \\
\hline
\end{tabular}




\subsection{Conclusions}

The baseline study was done to describe and evaluate the state of the art of potato production in the Rangpur district of Bangladesh for the introduction of the late blight alert service to potato farmers. The study comprises information from the different project activities of 2017 ranging from field trips, characterisation of the late blight genotypes prevailing in Rangpur, a dedicated baseline survey carries out under potato farmers in Rangpur, information from literature and from stakeholders in the potato value chain.

The conclusions of the baseline study with respect to the methodology are:

- The baseline survey was performed in between potato growing seasons and used the farmers' memory to answer the questions, which may therefore be considered to have a more general character than answers for a specific potato production. This should be kept in mind when reading the results and conclusions.

- The results may be not completely representative for potato farmers in Rangpur, because the farmers' survey was carried out under predominantly larger farmers.

- The questionnaire included the entire list of allowed fungicides for late blight control in Bangladesh, which was a major improvement compared to the approach used in Munshiganj.

- The chosen methodology of interviewing farmers on their behaviour, needs, bottlenecks and barriers with respect to late blight control yielded very useful information, which is a solid starting point to introduce the late blight alert service.

The conclusions of the baseline study with respect to the survey are that:

- Farmers have a great need to improved control of late blight.

- Farmers are eager to learn about improved strategies to control late blight.

- Late blight pressure is severe due to climatological conditions.

- Farmers' awareness of late blight is high.

- In general, farmers timely spray preventive fungicides but effectiveness of sprays is unclear and late blight is observed by farmers.

- Farmers apply mainly curative Metalaxyl containing fungicides, which have little/no effect on the control of the found Metalaxyl resistant strain of late blight in Rangpur.

- Other options to reduce late blight related yield losses might be included as a package to reduce losses.

The conclusion of the baseline study with respect to the outcome indicators are that:

- The starting point for the different indicators shows high potential to be improved as the late blight alert service is introduced.

The need for the late blight alert service was clearly identified in this study. However, some potential bottlenecks have also been identified and which may be difficult to change or improve during the project period. The two most important pitfalls are: 
- The availability and use of counterfeit fungicides may lead to a disappointing control of late blight, even if farmers use the alert service. Due to counterfeit fungicides, trust in the service may be lost hampering adoption.

- The unavailability of adequate fungicides to control preventively and curatively late blight including the Metalaxyl resistant strain Blue13, might compromise an effective introduction and effective use of the alert service. This conclusion holds for Rangpur as it did for Munshiganj and may well be for all potato producing regions in Bangladesh. 


\section{References}

Agricultural Wing, 2017. Estimates of potato 2016-16, Government of the People's Republic of Bangladesh, Bangladesh Bureau of Statistics, Dhaka, $8 \mathrm{pp}$.

Anonymous, 2017. Estimates of potato 2016-17, Government of the People's Republic of Bangladesh Bangladesh Bureau of Statistics Agricultural Wing, Dhaka, 6 pp.

Bangladesh Bureau of Statistics (BBS), 2013. District Statistics 2011 Rangpur. Bangladesh Bureau of Statistics, Ministry of Planning, Dhaka $102 \mathrm{p}$.

Bangladesh Bureau of Statistics (BBS), 2016. Yearbook of Agricultural Statistics-2016. Bangladesh Bureau of Statistics, Ministry of Planning, Dhaka $571 \mathrm{p}$.

Dey T., M. Hossain, M. Kadian, S. Hossain, M. Bonierbale and A. Mahmud, 2010. Prevalence, epidemiology and management of potato late blight in Bangladesh. Potato Journal 37, 99102.

Egger U., 2012. Potato Processing in Bangladesh: The Rolling Stone. 7 April.

FRG, 2012. Fertilizer Recommendation Guide. Bangladesh Agricultural Research Council (BARC), Farmgate, Dhaka 1215. 274 p.

Haque A., A.S.M. Nahiyan and M.A. Siddique, 2018. Production Storage and Marketing of Table Potatoes in Selected Areas of Bangladesh: An In-depth Study, Bangabandhu Sheikh Mujibur Rahman Agricultural, Advanced Seed Research \& Biotech Centre, Advanced Chemical Industries, Dhaka, Bangladesh, $39 \mathrm{pp}$.

Haque M., M. Hossain, M. Islam, M. Waliullah and T. Dey, 2013. Effect of planting time and fungicidal spray in controlling late blight of potato variety Raja. Journal of Agroforestry and Environment 7, 123-126.

Hoque M. and M. Sultana, 2012. Integrated crop management in potato through farmers' field school with special reference to women. The Journal of Plant Protection Sciences 4, 40-51.

Kawochar M., H. C. Mohanta, M. A. Hossain, B. K. Goswami and M. J. Uddin, 2014. Diversity of tuber crops in Bangladesh.

Li Y., F. Govers, O. Mendes, A. Testa, E. Jacobsen, S. Huang and T. Van der Lee, 2010. A new set of highly informative SSR markers for Phytophthora infestans population analysis assembled into an efficient multiplex. Mol. Ecol. Resour 10, 1098-1105.

Pronk A.A., N. Islam, H. Ahsan, M.M. Rahman, G.J.T. Kessel and H. Hengsdijk, 2017. Baseline study GEOPOTATO, Wageningen University and Research Centre, Wageningen, $59 \mathrm{pp}$.

Rabbani M.G., M.A. Siddique, M.M. Islam and M.S. Islam, 2010. The potato sector in Bangladesh: its challenges and opportunities. Katalyst, Dhaka, Bangladesh. 144 p. 


\section{Annex I: Fertilizer Recommendation Guide: Root and Tuber Crops: Potato (Solanum tuberosum) (FRG 2012)}

\begin{tabular}{llllllllll}
\hline \multicolumn{1}{c}{ Nutrient recommendation $(\mathrm{kg} / \mathrm{ha})$} & \multicolumn{1}{c}{} & \multicolumn{3}{c}{ Manure (ton/ha) } \\
\hline $\begin{array}{llllllll}\text { Soil analysis } \\
\text { Interpretation }\end{array}$ & $\mathrm{N}$ & $\mathrm{P}$ & $\mathrm{K}$ & $\mathrm{S}$ & $\mathrm{Mg}$ & $\mathrm{Zn}$ & $\mathrm{B}$ & Cow dung & $\begin{array}{c}\text { Poultry } \\
\text { manure }\end{array}$ \\
\hline Optimum & $0-45$ & $0-10$ & $0-45$ & $0-5$ & - & - & - & 5 & 3 \\
Medium & $46-90$ & $11-20$ & $46-90$ & $6-10$ & $0-5$ & $0-2$ & $0-0.5$ & 5 & 3 \\
Low & $91-135$ & $21-30$ & $91-135$ & $11-15$ & $6-10$ & $3-4$ & $0.6-1.0$ & 5 & 3 \\
Very low & $136-180$ & $31-40$ & $136-180$ & $16-20$ & $11-15$ & $5-5$ & $1.1-1.5$ & 5 & 3 \\
\hline
\end{tabular}

Method of application:

1. All of organic manure, phosphorus, sulphur, magnesium, zinc and boron and half of the nitrogen and potassium should be applied as basal during final preparation

2. Remaining half nitrogen and potassium should be applied as side dressing at 30-50 days after planting during earthing up operation. 


\section{Annex II: GEOPOTATO Baseline questionnaire Rangpur (2016-17)}

\begin{tabular}{|c|c|c|}
\hline $\mathrm{Q}$ & Question & Unit/response option \\
\hline 1 & Select District & Rangpur \\
\hline 2 & Select sub-district & $\begin{array}{l}\text { Dropdown list: Badarganj/Gangachara/Kaunia/Mithapukur/Pirgachha/ } \\
\text { Pirganj/Rangpur Metro \& Sadar/Taraganj }\end{array}$ \\
\hline 3 & Write farmer's name & Input type \\
\hline 4 & Select farmer's gender & Male/Female \\
\hline 5 & Mobile number of interviewed person & Input type-Numeric \\
\hline 6 & Level of education & Dropdown list: Primary/Secondary/Higher Secondary/No Education \\
\hline 7 & Land size of the potato plot (decimel) & Input type-Numeric \\
\hline 8 & Previous crop & Dropdown list: Crop preceding the potato crop \\
\hline 9 & Potato variety & Dropdown list: varieties \\
\hline 10 & Source (origin) of Potato Seed & $\begin{array}{l}\text { Dropdown list: Own harvest/certified purchased/uncertified seed } \\
\text { purchased/do not know }\end{array}$ \\
\hline 11 & Week of planting & Single Select -week number of the year \\
\hline 12 & $\begin{array}{l}\text { Do you use whole potato seed of cut seed at } \\
\text { planting? }\end{array}$ & Dropdown list: Whole/cut/do not know \\
\hline 13 & Planting distance in row (plant to plant distance)(cm) & Input type-Numeric \\
\hline 14 & $\begin{array}{l}\text { Planting distance between rows (row to row } \\
\text { distance) } \mathrm{cm}\end{array}$ & Input type-Numeric \\
\hline 15 & Amount of urea used & Input type-Numeric \\
\hline 16 & Amount of MoP used & Input type-Numeric \\
\hline 17 & Amount of TSP used & Input type-Numeric \\
\hline 18 & Number of fungicide treatments & Input type-Numeric \\
\hline 19 & Fungicide name chemicals used & Dropdown list: 217 product names \\
\hline 20 & First application against late blight & Single Select -week no of the year \\
\hline 21 & First observation of late blight by farmer in his plot & Single Select -week no of the year \\
\hline 22 & AVERAGE Late blight spray interval & Input type-Numeric \\
\hline 23 & Type of equipment used for spraying & Dropdown list: Knapsack/power sprayer/ both \\
\hline 24 & Late blight infection level & Dropdown list: Low/Medium/High \\
\hline 25 & Harvest date & Dropdown list: Single Select -week no of the year \\
\hline 26 & Yield of plot (kg/decimal) & Input type-Numeric \\
\hline 27 & Selling price potato directly after harvest (tk/kg) & Input type-Numeric \\
\hline 28 & How much of the yield is/will be stored $(\mathrm{kg})$ & Input type-Numeric \\
\hline 29 & Did you hear about the SMS service? & Dropdown list: yes/no \\
\hline 30 & $\begin{array}{l}\text { Did SMS farmers or DAE staff tell you about the } \\
\text { message they had received? }\end{array}$ & Dropdown list: yes/no \\
\hline 31 & $\begin{array}{l}\text { If yes, did you spray according the message you } \\
\text { receive from the fellow farmer or DAE? }\end{array}$ & Dropdown list: yes/no \\
\hline 32 & If no, why not? & $\begin{array}{l}\text { Dropdown list: I did not trust/Had no time/did not have fungicide/I had } \\
\text { sprayed just before receiving message /other reason }\end{array}$ \\
\hline 33 & $\begin{array}{l}\text { Would you like to receive SMS on control of Late } \\
\text { Blight spraying in the future? }\end{array}$ & Dropdown list: yes/no \\
\hline 34 & If no, why not? & Dropdown list: I do not trust/I will hear from fellow farmer or DAE/other \\
\hline 35 & If yes, would you be willing to pay for it? & Dropdown list: yes/no \\
\hline 36 & If yes, how much? & Input type-Numeric \\
\hline 37 & Location of interview & Dropdown list: Respondent Residence/Outside of Respondent Residence \\
\hline 38 & If outside, distance from home & Input type-Numeric \\
\hline
\end{tabular}

